OPEN ACCESS

Edited by:

Willem Van Eden,

Utrecht University, Netherlands

Reviewed by:

Lara Campana,

University of Edinburgh,

United Kingdom

Nicolas Riteau,

National Institutes of Health (NIH),

United States

*Correspondence:

Jixin Zhong

zhongiixin620@163.com

Boxu Ren

boxuren188@163.com

Specialty section:

This article was submitted to Inflammation,

a section of the journal

Frontiers in Immunology

Received: 20 August 2017 Accepted: 07 November 2017 Published: 27 November 2017

Citation:

Yang Y, Liu L, Naik I, Braunstein Z, Zhong J and Ren B (2017)

Transcription Factor C/EBP

Homologous Protein in

Health and Diseases.

Front. Immunol. 8:1612. doi: 10.3389/fimmu.2017.01612

\section{Transcription Factor C/EBP Homologous Protein in Health and Diseases}

\author{
Yuan Yang ${ }^{1,2}$, Lian Liu', Ishan Naik4, Zachary Braunstein ${ }^{5}$, Jixin Zhong ${ }^{4 *}$ and Boxu Ren ${ }^{1,2 *}$ \\ ${ }^{1}$ Center for Molecular Medicine, Medical School of Yangtze University, Jingzhou, China, ${ }^{2}$ Department of Radiology, Medical \\ School of Yangtze University, Jingzhou, China, ${ }^{3}$ Department of Pharmacology, Medical School of Yangtze University, \\ Jingzhou, China, ${ }^{4}$ Cardiovascular Research Institute, Case Western Reserve University, Cleveland, OH, United States, \\ ${ }^{5}$ Boonshoft School of Medicine, Wright State University, Dayton, $\mathrm{OH}$, United States
}

C/EBP homologous protein (CHOP), known also as DNA damage-inducible transcript 3 and as growth arrest and DNA damage-inducible protein 153 (GADD153), is induced in response to certain stressors. $\mathrm{CHOP}$ is universally acknowledged as a main conduit to endoplasmic reticulum stress-induced apoptosis. Ongoing research established the existence of CHOP-mediated apoptosis signaling networks, for which novel downstream targets are still being determined. However, there are studies that contradict this notion and assert that apoptosis is not the only mechanism by which $\mathrm{CHOP}$ plays in the development of pathologies. In this review, insights into the roles of $\mathrm{CHOP}$ in pathophysiology are summarized at the molecular and cellular levels. We further focus on the newest advances that implicate $\mathrm{CHOP}$ in human diseases including cancer, diabetes, neurodegenerative disorders, and notably, fibrosis.

Keywords: C/EBP homologous protein, apoptosis, endoplasmic reticulum stress, fibrosis, cancer, neurodegenerative disorders, diabetes

\section{INTRODUCTION}

C/EBP homologous protein (CHOP), also known as growth arrest and DNA damage-inducible protein 153 (GADD153), belongs to the CCAAT/enhancer-binding protein (C/EBP) family. Much of our understanding of $\mathrm{CHOP}$ originates from the roles it plays during endoplasmic reticulum (ER) stress (1) and amino acid limitation (2). It was gradually discovered as a stress-responsive transcription factor during growth arrest, DNA damage, nutrient deprivation, hypoxia, genotoxic agents, etc. CHOP expression is induced by unfolded protein response (UPR) and integrated stress response (ISR) $(3,4)$, primarily through the PRKR-like ER kinase (PERK) pathway. As a nuclear transcription regulator, $\mathrm{CHOP}$ also controls numerous genes involved in multifaceted cellular processes including inflammation, differentiation, autophagy, and apoptosis. A considerable aspect of CHOP's involvement in disease is evident in the fact that sustained CHOP activation has long been accepted as a pivotal trigger for ER stress-related apoptosis.

In eukaryotic cells, the ER is a specialized organelle with the capacity for synthesis and storage of calcium as well as the folding and transport of secretory proteins to maintain cellular proteostasis. However, intrinsic and extrinsic insults, such as perturbations in calcium homeostasis and redox status, disturb ER proteostasis and cause accumulation of unfolded or misfolded proteins, collectively termed ER stress. In response, cells activate a series of adaptive pathways, namely the UPR, to restore homeostasis. Another innate protective pathway to proteostatic regulation is the ISR (5). 
Literature on the role of ER stress (or protein misfolding) and UPR in numerous disease states, such as cancer, neurodegenerative disease, metabolic disease, and genetic disorders, has been well reviewed (6-8). To penetrate into the significance of $\mathrm{CHOP}$ in pathological processes, it is important to have a full overview of several aspects of CHOP. In this review, we delineate its structure and characteristics. The regulating mechanisms of CHOP at the transcriptional level and its functions-primarily apoptosis are summarized in detail. Finally, the latest studies targeting $\mathrm{CHOP}$ will be highlighted in four classifications of human disease, with special attention to fibrosis, for which the targeting of $\mathrm{CHOP}$ as a therapeutic approach has not yet been reviewed.

\section{CHARACTERIZATION AND MOLECULAR FUNCTION OF CHOP}

C/EBP homologous protein, encoded by the DNA damageinducible transcript 3 (Ddit3) gene, is one of the six identified members of C/EBP trans-acting factors that bind to the CCAAT box motif present in several promoters. $\mathrm{CHOP}$ is characterized by transcriptional activation/repression domains at its $\mathrm{N}$-terminus and a C-terminus basic-leucine zipper (bZIP) domain which contains a basic region mediating sequence-specific DNA binding along with a leucine zipper motif for dimerization. The $\mathrm{N}$-terminal region is necessary for proteasomal degradation of $\mathrm{CHOP}$. A serine/threonine-rich motif (97-100) in its transactivation domain can be recognized by speckle-type POZ protein (SPOP), which triggers CHOP degradation via the ubiquitin-proteasome pathway (9). Similarly, macrophage AMP-activated protein kinase $\alpha 1$ mediates $\mathrm{CHOP}$ ubiquitination and proteasomal degradation via phosphorylation at the serine residue (30) (10). Two serine residues $(79,82)$ are responsible for $\mathrm{CHOP}$ phosphorylation by p38 mitogen-activation protein kinase (p38 MAPK) (11). This phosphorylation event enhances its transactivation activity and is required for CHOP-induced apoptosis in macrophages (12) (Figure 1). It is well known that the conservation of CHOP's bZIP domain provides a platform for the formation of heterodimers. Furthermore, the basic region of $\mathrm{CHOP}$ holds proline and glycine residues that interrupt DNA-binding activity of the protein, causing increased heterodimerization with other C/EBPs (13). The homotypic heterodimers uniquely bind to the sequence $(\mathrm{A} / \mathrm{G})$ TGCAAT(A/C)CCC in response to stress (14). CHOP can also dimerize with members of another bZIP subgroup, the CREB/ activating transcription factor (ATF) family. Consistently, a C/ EBP-ATF-binding site is present in the amino acid response elements (AARE) of CHOP promoter (15). It has also been reported that the bZIP domain is required for CHOP-induced apoptotic processes $(16,17)$. Tribbles-related protein 3 (TRB3) recognizes the region between amino acid (aa) 10 and 18 to interact with CHOP.

$\mathrm{C} / \mathrm{EBP}$ homologous protein serves as a double-edged transcription factor. It was originally proposed to be a dominant-negative regulator for other $\mathrm{C} / \mathrm{EBP}$-induced transcription by forming dimers and impairing their DNA-binding activity (18). However, CHOP also negatively regulates ATF4-dependent induction of the ASNS gene during ER stress or amino acid deprivation (19). Indeed, microarray analysis shows CHOP overexpression inactivates the expression of most of the target genes, serving as a dominant-negative factor by sequestration of dimer forming transcription factor partners (20). Nevertheless, subsequent studies have shed light on the positive role of $\mathrm{CHOP}-\mathrm{C} / \mathrm{EBP}$ interaction in transcriptional activation $(21,22)$ and have also revealed that $\mathrm{CHOP}-\mathrm{ATF} 4$ heterodimers induce the expression of numerous stress-responsive genes (23).

\section{REGULATION OF CHOP}

$\mathrm{C} / \mathrm{EBP}$ homologous protein is a cellular stress sensor that can be induced in response to a series of physiological or stress conditions such as ER stress, nutrient deprivation, DNA damage, cellular growth arrest, and hypoxia $(1,2,24)$. It expresses at a very low level in normal physiology, but cellular stress leads to high-level expression. CHOP is acknowledged as a specific and convergent transcription factor of ER stress and its expression is generally modulated at the transcriptional level. CHOP transcription can be regulated via ER stress response elements (ERSE) and the C/EBP-ATF response element (CARE) of its promoter in response to cellular stress $(15,25)$, and via amino acid response elements (AARE) under amino acid starvation conditions (26) (Figure 2).

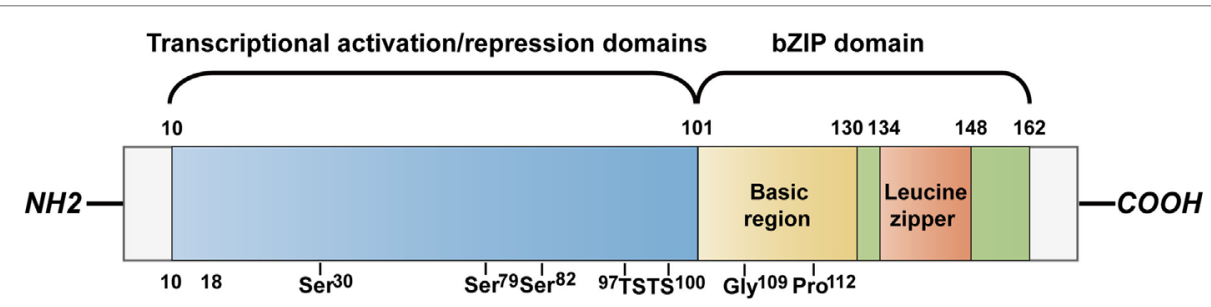

FIGURE 1 | CHOP structure. CHOP is a protein containing 169 amino acids that divide into N-terminus transcriptional activation/repression domains and a C-terminus bZIP domain including a basic region for DNA binding and a leucine zipper region for dimerization. The motif between aa 10 and 18 is for interaction with TRB3. The transactivation domain contains a serine residue (30) that is phosphorylated by AMPK $\alpha 1$ to trigger the proteasomal degradation of $\mathrm{CHOP}$ in macrophages. It is also degraded by SPOP that recognizes the serine/threonine-rich motif between aa 97 and 100. Phosphorylation at two serine residues (79, 82) by p38 MAPK enhances the transcriptional activation by CHOP. The basic region holds glycine (109) and proline (112) substitutions interrupting the DNA-binding activity. CHOP, C/EBP homologous protein; bZIP, basic-leucine zipper; SPOP, speckle-type POZ protein; P38 MAPK, p38 mitogen-activation protein kinase; aa, amino acid. 


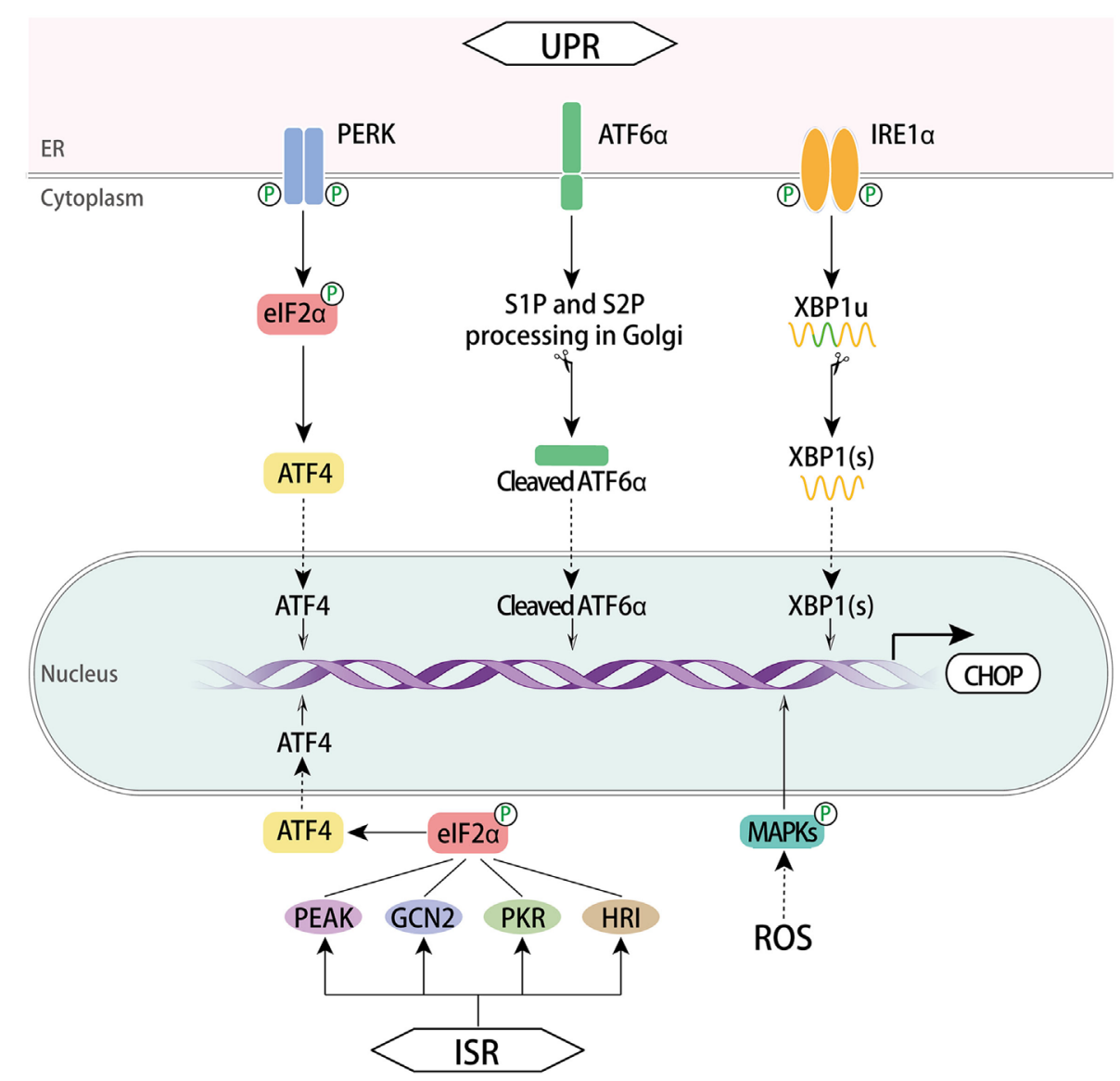

FIGURE 2 | Regulation of CHOP. The three signaling branches of UPR lead to CHOP transcription respectively. Once activated via dimerization and transautophosphorylation, PERK phosphorylates elF2 $\alpha$, which enables ATF4 translation. Subsequently, CHOP is activated by ATF4 trafficking to the nucleus. In the presence of misfolded proteins, ATF6 $\alpha$ translocates to the Golgi apparatus where it was processed by the protease SP1 and SP2, thus producing a cytosolic fragment ATF6f to regulate CHOP activation in the nucleus. Activation of IRE1 $\alpha$ RNase domain processes unspliced XBP1 mRNA to create activated XBP1(s), which enters the nucleus and controls the expression of CHOP. Another pathway involves ISR. This response is initiated with GCN2, PKR, HRI, and PEAK that converge on the phospho-elF2 $\alpha$ /ATF4 pathway and CHOP induction ensues. A ROS-dependent mechanism also activates CHOP via MAPKs. CHOP, C/EBP homologous protein; UPR, unfolded protein response; ISR, integrated stress response; ATF, activating transcription factor; ATF6 $\alpha$, activating transcription factor $6 \alpha$; PERK, PRKR-like ER kinase; XBP1, X box-binding protein 1; GCN2, general control nonderepressible 2; PKR, RNA-dependent protein kinase; HRI, heme regulated inhibitor; ROS, reactive oxygen species; MAPKs, mitogen-activated protein kinases; elF2 $\alpha$, eukaryotic translation initiator factor $2 \alpha$.

\section{Unfolded Protein Response}

Endoplasmic reticulum stress induces UPR, an adaptive mechanism that controls cell fate between survival and death in an intensity time-dependent manner. It involves three signal transduction pathways initiated by three ER transmembrane proteins: PERK, inositol requiring protein $1 \alpha$ (IRE1 $\alpha$, also known as ERN1), and activating transcription factor $6 \alpha$ (ATF6 $\alpha)(27$, 28). Each of the three maintains an inactive state in combination with the ER chaperone BiP (also named GRP78) in resting cells. Under chronic or overwhelming ER stress, all three mammalian UPR pathways uniquely lead to the initiation of CHOP transcription through binding sites within CHOP's promoter. The cis-acting AARE1 and AARE2 as well as the composite CARE (29) are bound by ATF4, while ATF $6 \alpha$ and X box-binding protein 1 (XBP1) bind to ERSE1 and ERSE2.

The PERK pathway is predominant in CHOP activation. Upon the luminal binding of misfolded proteins, PERK is activated through dimerization and trans-autophosphorylation (30). It phosphorylates eukaryotic translation initiator factor $2 \alpha$ (eIF2 $\alpha$ ), which then attenuates global protein synthesis. Upon activation, ATF4 translocates into the nucleus and transcriptionally upregulates $C H O P$ as well as many UPR genes that are vital for amino acid metabolism and redox processes (31).

The activation of IRE1 $\alpha$ is similar to PERK in that its luminal domains are first dimerized and then are trans-autophosphorylated. Activated IRE $1 \alpha$ creates spliced XBP1(s) by cleaving a 26-nucleotide intron from the mRNA of unspliced XBP1 using a cytoplasmic RNase domain. IRE1 $\alpha$ also mediates regulated IRE1-dependent decay of selective mRNAs (32). XBP1(s) enters the nucleus and induces the transcription of genes correlated with protein-folding capacity and ER-associated degradation. Hence, $\mathrm{CHOP}$ expression is upregulated by $\mathrm{XBP} 1(\mathrm{~s})(33,34)$.

In the ATF6 $\alpha$ branch, the type II ER located protein ATF6 $\alpha$ is transported to the Golgi apparatus where it is processed by 
Site-1 and Site-2 proteases (SP1 and SP2, respectively). As a consequence of this processing, a cytosolic fragment of ATF $6 \alpha$ is produced and enters the nucleus to regulate the expression of target genes, including $\mathrm{BiP}$ and $\operatorname{CHOP}(35,36)$. Along with XBP1(s), ATF6 fontributes to the augmentation of ER size and ER protein-folding capacity through target genes.

\section{Integrated Stress Response}

Integrated stress response serves as another cytoprotective mechanism against various stressors, such as ER stress, nutrition stress, oxidative stress, proteasome inhibition, hyperoxia, or viral infection $(5,37,38)$. This common adaptive response initiates with four kinases consisting of general control nonderepressible 2, RNA-dependent protein kinase (39), heme regulated inhibitor, and PEAK, all four of which then converge on a core event, the phospho-eIF2 $\alpha /$ ATF4 pathway, which in turn increases the transcription of CHOP $(4,40)$.

\section{Reactive Oxygen Species (ROS)-MAPKs}

Reactive oxygen species disturb redox status and ER homeostasis, thus inducing ER stress responses. ROS have been reported to activate $\mathrm{CHOP}$ through the AP-1 element in the $\mathrm{CHOP}$ promoter (41). The MAPKs consisting of JNK, p38 MAPK, and ERK are canonical downstream mediators of ROS (42). There are a number of studies establishing the signaling axis of ROS-induced CHOP upregulation via MAPKs signaling pathways in different cells. The ROS-MAPKs-CHOP pathway has been reported to suppress migration of hepatocellular carcinoma (HCC) cells (43) and mediate the downstream death receptor pathway in a number of cancer cells (44-47). Moreover, a scavenger of ROS diminished the PERK/ eIF2 $\alpha / C H O P$ pathway (48). IRE1 can recruit TRAF2 to activate ASK1, which can, through different pathways, induce expression of JNK and p38 MAPK (49). Phosphorylation of CHOP by p38 MAPK is required for its activation. Thus, the way by which ROS activates MAPKs and CHOP may be the IRE1 $\alpha$ or PERK pathway of UPR (50). The ATF4/ATF3 axis was also reported to induce CHOP expression under ROS-dependent ER stress $(51,52)$.

\section{Others}

Several members of the CREB/ATF transcription factor family are capable of regulating $\mathrm{CHOP}$ expression. ATF3 can interact with the CARE elements within the CHOP promoter (29), while ATF5 activates the AARE1 site (53) under arsenite exposure. ATF2 binds the AARE sequence to regulate $\mathrm{CHOP}$ transcription in response to amino acid starvation (54). Conversely, some factors can inhibit the expression of CHOP, thereby reducing its detrimental effects. At early stage of ER stress, miR-211 expression, induced by PERK activation, can suppress CHOP transcription through histone methylation at its promoter (55). CHOP expression can also be repressed through toll-like receptor (TLR)-TRIF-dependent pathway which increases the activity of eIF2B to counteract the effect of p-eIF2 $\alpha$ under the treatment of LPS, a TLR4 ligand in vitro and in vivo. Furthermore, the activation of eIF2B by TLR-TRIF signaling is attributed to serine dephosphorylation of eIF2Be by protein phosphatase $2 \mathrm{~A}$. When TRIF was deficient in mice, $\mathrm{CHOP}$ induction, apoptosis, and organ dysfunction ensued $(56,57)$.

\section{CELLULAR FUNCTION OF CHOP}

In addition to its pro-apoptotic role, the function of CHOP in regulating other cellular processes has recently come to light. CHOP serves as a multifunctional transcription factor that contributes to cellular functions including apoptosis, autophagy, inflammation, cell differentiation, and proliferation. Under nonstressed conditions, the subcellular location of $\mathrm{CHOP}$ is mainly in the cytoplasm where it negatively affects cell migration-associated genes, while stress conditions lead to its nucleus translocation, partly via LIP, a C/EBP $\beta$ isoform (58), and its DNA-binding capacity therefore allows it to regulate gene expression. Nuclear CHOP can induce a transient cell cycle arrest in $G_{1}$ phase (20). During ER stress, CHOP also inhibits the growth arrest-specific p20K genes, which are a group of genes that activate reversible $G_{0}$ arrest to regulate cell proliferation (59). Generally, it is known as an important node in the transcription factor network that dominates stress-inducible regulation of specific target genes. $\mathrm{CHOP}$ deficiency does not produce a substantial phenotype without a stress signal.

\section{CHOP in Apoptosis Modulation and Signaling}

During a stress situation, UPR attempts to increase proteinfolding capacity and remove misfolded and unfolded proteins. If the remedy is inadequate to restore homeostasis under chronic ER stress, terminal UPR will trigger apoptosis through abundant signaling mechanisms, mainly mediated by CHOP, JNK, and caspase-12, with CHOP as the most widely studied (60). It is notable that CHOP expression itself is not sufficient to induce apoptosis unless exposed to a stress signal. Studies in both cellular and animal models with $C H O P$ gene deficiency have shed light on the pro-apoptotic role of CHOP during cellular stress (61, 62). Synoptically, CHOP-dependent apoptosis is mainly mediated by altering the expression of pro-apoptotic or anti-apoptotic genes, either directly or indirectly $(1,63)$. Both the intrinsic, mitochondrial pathway and extrinsic, death receptor pathway of classic apoptosis can be activated by $\mathrm{CHOP}$ and proceed with a set of initiator caspases and common executioner caspases (64). Overall, the apoptotic pathways mediated by downstream targets of CHOP form networks (Figure 3), wherein the molecular interaction mechanisms remain to be further understood.

\section{Bcl-2 Family}

The B-cell lymphoma 2 (BCL2) family of proteins includes anti-apoptotic members, such as BCL2-like, and pro-apoptotic members, such as BH3-only and BAX-like. As a widely cited mechanism for the mitochondrial apoptotic pathway, $\mathrm{CHOP}$ induces the upregulation of certain $\mathrm{BH} 3$-only proteins, such as BIM (65), PUMA (66), while inhibiting the expression of BCL2 to release its sequestration of $\mathrm{BH} 3$-only proteins (67). Thus, they regulate $\mathrm{BAX}-\mathrm{BAK}$ homo-dimerization and consequent mitochondrial outer membrane permeabilization, causing release of cytochrome $c$ and stimulation of an apoptotic signaling cascade (68). A recent study pointed to a role for BOK, another BAX-like protein, in regulating ER stress-induced apoptosis through $\mathrm{CHOP}$ 


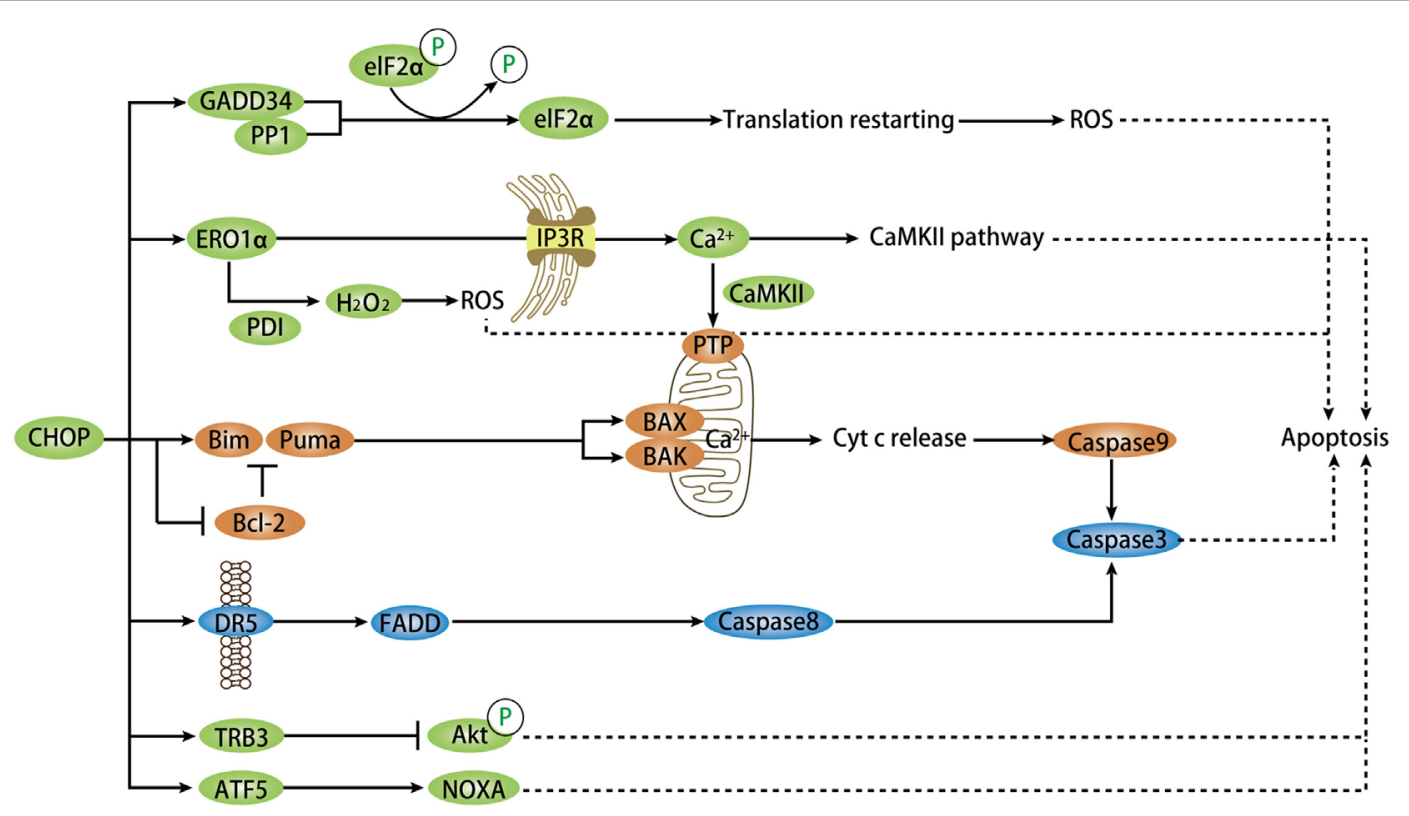

FIGURE 3 | Model depicting targets of CHOP-dependent apoptosis. During chronic ER stress, CHOP activation mediates pro-apoptosis signaling via numerous targets and pathways directly or indirectly. CHOP triggers the intrinsic apoptotic pathway through inhibition of BCL-2 and upregulation of BIM and PUMA, which regulate BAX-BAK-mediated mitochondrial outer membrane permeabilization. This leads to cytochrome $c$ release and caspase cascade. $\mathrm{CHOP}$ also directly induces the expression of DR5-mediating extrinsic apoptotic pathway via FADD and caspase8-mediated cascade. In normal conditions, CHOP-dependent ERO1 $\alpha$ induction oxidizes PDI to produce ROS that plays a critical role in apoptosis. The ERO1 $\alpha-I P 3 R-\mathrm{Ca}^{2+}-\mathrm{CaMKIl}$ pathway, in addition to ROS, can trigger several apoptotic pathways, primarily the $\mathrm{Ca}^{2+}$-dependent mitochondrial apoptosis via PTP. GADD34 is a key target of CHOP and ATF4 and combines with PP1 to promote dephosphorylation of phospho-elF2 $\alpha$. This event renews protein translation that promotes apoptosis in certain stress settings. Another target is TRB3 that prevent Akt phosphorylation in this apoptotic pathway. ATF5, downstream of CHOP, facilitates apoptosis through activation of some pro-apoptotic genes, such as NOXA. CHOP, C/EBP homologous protein; ER, endoplasmic reticulum; ATF, activating transcription factor; ROS, reactive oxygen species; DR5, death receptor 5; FADD, Fas-associated death domain; GADD34, growth arrest and DNA-damage-inducible protein 34; PP1, protein phosphatase 1; PDI, protein disulfide isomerase; $\mathrm{CaMKII}, \mathrm{Ca}^{2+} /$ calmodulin-dependent protein kinase II; TRB3, tribbles-related protein 3; ERO1 $\alpha$, ER oxidase $1 \alpha$.

as evidenced by diminished activation of CHOP, diminished activation of BIM and apoptosis in Bok ${ }^{-/-}$mice (69).

\section{Death Receptor 5 (DR5)}

$\mathrm{C} / \mathrm{EBP}$ homologous protein has been proven to directly control the transcription of the TNF family member cell-surface DR5, which activates the adaptor Fas-associated death domain to trigger caspase8-induced apoptosis (70). The CHOP-DR5 model sensitizes several chemically challenged cancer cells to extrinsic apoptosis mediated by ROS in vitro $(44,71)$, and ATF4 both in vivo and in vitro (72). During this process, the upstream signaling of CHOP includes ATF4, ROS-MAPKs, or the ATF4-ATF3 axis $(46,52)$.

\section{Growth Arrest and DNA-Damage-Inducible Protein 34 (GADD34)}

During prolonged ER stress, PERK-induced CHOP expression directly upregulates the transcription of GADD34, which forms a complex with its cofactor protein phosphatase 1 to facilitate dephosphorylation of phospho-eIF $2 \alpha$ and protein translation $(63,73)$. However, if the feedback protein synthesis increase does not revert proteostasis, GADD34 upregulation can cause further misfolded proteins aggregation and ROS production to promote apoptosis.

\section{ER Oxidase $1 \alpha($ ERO1 $\alpha)$}

Reactive oxygen species-dependent oxidative stress in ER stress is induced by the CHOP target ERO1 $\alpha$ (74). Normally, ERO $1 \alpha$ is responsible for disulfide bond formation by oxidizing protein disulfide isomerase. This process is coupled with the production of hydrogen peroxide $\left(\mathrm{H}_{2} \mathrm{O}_{2}\right)$, which raises ROS generation and causes cell death if excessively produced (75). This is in line with another report on CHOP knockdown that showed decreased $\mathrm{H}_{2} \mathrm{O}_{2}$ formation and ROSinduced apoptosis (76). Faced with stress, CHOP activates calcium-mediated apoptosis through $\mathrm{ERO} 1 \alpha$, which activates inositol-1,4,5-trisphosphate receptor $\left(\mathrm{IP}_{3} \mathrm{R}\right)$, the ER calcium channel that mediates $\mathrm{Ca}^{2+}$ efflux (77). As a result, the cytosolic $\mathrm{Ca}^{2+}$ activates $\mathrm{Ca}^{2+} /$ calmodulin-dependent protein kinase II (CaMKII) that triggers multiple apoptotic pathways including JNK signaling. The ROS signal generated from one of these pathways can conversely amplify CHOP activation via a positive feedback loop (31). Another pathway is that of CaMKII, which promotes the uptake of $\mathrm{Ca}^{2+}$ by mitochondria through mitochondrial permeability transition pores to activate a mitochondrial apoptotic pathway (78). Collectively, ERO $1 \alpha$ induces oxidative stress and $\mathrm{Ca}^{2+}$-mediated mitochondrial impairment in ER-stressed cells, which lead to CHOPdependent apoptosis. 


\section{Tribbles-Related Protein 3 (TRB3)}

Past research has demonstrated that $\mathrm{CHOP}-\mathrm{ATF} 4$ cooperates to transactivate the transcription activity of TRB3 that contributes to CHOP-induced apoptosis in various cells types, such as cardiomyocytes (79). TRB3 binding to prevent Akt phosphorylation is probably the underlying mechanism of its pro-apoptotic function (80). The binding site of CHOP overlaps the amino-acid response elements in TRB3 promoter and respective specific regions in $\mathrm{CHOP}$ and $\mathrm{TRB} 3$ protein are responsible for their interaction (81).

Han and his colleagues have proposed a novel mode of CHOP-induced apoptosis where CHOP-ATF4 heterodimer binds to promoters of genes involved in protein synthesis, such as Gadd34, Trb3, Atf3, and Wars. Forced expression of CHOP and ATF4 evokes increased protein synthesis, consequent ATP depletion, and oxidative stress, thereby leading to cell death (23). This is in line with previous research on CHOP knockouts that showed less protein aggregation, ROS, and apoptosis $(63,82)$. Advances made in understanding the mechanism of ER stressinduced apoptosis have recently gained new impetus for the analysis of microRNAs in cells challenged with the ER stressor tunicamycin (TUN). For example, the miR-216b is proved to be a direct target of CHOP and thereby executes its pro-apoptotic activity by suppression of c-Jun expression (83). Full induction of ATF5 expression requires the upstream regulation of CHOP and the CARE element of its promoter can be bound by ATF4 and CHOP. As such, ATF5 potentiates CHOP-dependent apoptosis through activation of pro-apoptotic genes, including NOXA, during proteostasis imbalance (84). Another novel target of CHOP-mediated apoptosis is $\mathrm{p} 21$, a prominent cell cycle regulator with strong anti-apoptotic activity. The direct suppression of p21 transcription by CHOP is important for the pro-apoptotic pathway in vivo and in vitro $(85,86)$. CHOP also binds to the promoter of lipocalin 2, which mediates apoptosis in lung cancer cells in response to ER stress (87).

Recent research has also shown that CHOP does not elicit apoptotic processes under stress conditions in some specific cell types, such as myeloid-derived suppressor cells (MDSCs) (88) and myelinating glial cells (89). In light of the data, a distinct model of apoptosis proposed with an UPR cycle places CHOP in an obligatory step upstream of GADD34 that dephosphorylates p-eIF2 $\alpha$ and resumes global protein synthesis, which is the decisive matter of cell fate (89). In this context, cells attempt to restore homeostasis while events including calcium loss, ATP depletion, and oxidative stress, eventually lead to cell death. If cells survive these events, protein aggregation due to subsequent stress drives another UPR cycle. This is consistent with a previous study in mouse embryonic fibroblasts (MEFs) overexpressing CHOP that implies forced expression of $\mathrm{CHOP}$ alone is not sufficient to induce apoptosis (23).

\section{Autophagy}

To cope with an inadequate protein-folding environment in ER, cells activate autophagy, an early stress-adaptive self-eating process, responsible for lysosome-dependent degradation of protein aggregates and other cellular material through UPR signaling (90). Many cellular stresses can trigger autophagy or apoptosis depending on specific circumstances and autophagy usually precedes apoptosis. CHOP has been implicated in autophagy induced by amino acid starvation, ER stress, virus infection, and hypoxia.

During amino acid starvation and ER stress, CHOP binds to the promoters of a set of autophagy genes (91). The time course analysis provides a further understanding that its upregulation of autophagy genes is within a short period of leucine starvation in cells. However, as time goes on, CHOP turns to inhibit the activation of these genes. It also inhibits autophagic flux and the conversion of microtubule-associated protein 1A/1B-light chain 3B (referred to as LC3), which is a key step for autophagy formation. The UPR-controlled balance of cell fate is therefore inclined toward cell death (92). Moreover, CHOP modulates the induction of autophagosomes during ER stress, as evidenced by the inhibition of LC3-II expression and GFP-LC3B dots (93). The results also showed that CHOP upregulated IRE1 $\alpha$, which contributed to autophagy induction, but their specific role and relation in this autophagy pathway remain unknown. Similarly, CHOP-mediated Licochalcone A-induced autophagy in nonsmall cell lung cancer cells and HeLa cells, while knockdown of CHOP reversed autophagy by reducing LC3-II and GFP-LC3 expression (94). Another study implied that UPR-activated CHOP elicited complete autolysosome maturation in hepatitis C virus-induced autophagy via LC3B-II-dependent mechanism (95). In the context of hypoxia, CHOP induces the expression of the autophagy gene Atg5 by directly binding to its promoters (96).

\section{Cell Differentiation}

$\mathrm{C} / \mathrm{EBP}$ homologous protein is involved in the block of differentiation in mesenchymal lineages. It is a fundamental regulator of adipogenesis, a role that has been supported by numerous experiments. The terminal differentiation of adipocytes is necessary for efficient lipid storage. CHOP was initially found to negatively regulate adipocyte differentiation in vitro, in response to metabolic stress (97), hypoxia (98), and when phosphorylated by stress-induced p38 MAPK (11). In subsequent studies, both in vivo and in vitro adipocyte differentiation is inhibited by CHOP expression after PERK-eIF2 $\alpha$ activation during ER stress (99). As for the specific mechanisms, under polyamine depletion, $\mathrm{CHOP}$ exerts the inhibitory effect through interaction with $\mathrm{C} /$ $\mathrm{EBP} \beta$, thus impairing its role in the execution of mitotic clonal expansion process and in the transcriptional activation of peroxisome proliferator-activated receptor $\gamma(\mathrm{PPAR}-\gamma)$ and C/EBP $\alpha$; the predominant regulators of adipogenesis (100). This is consistent with the molecular mechanism whereby CHOP impairs the differentiation of preadipocyte in response to aging (101). Higher levels of CHOP have led to hyperplasia of adipose tissue with less differentiated adipocytes in mouse models and downregulation of CHOP mRNA is required for complete adipocyte differentiation of MEFs (102).

Besides adipocytes, CHOP was also identified as a negative modulator for osteoblast differentiation. In terms of the mechanism, CHOP inhibits the binding activity of $\mathrm{C} / \mathrm{EBP} \beta$ against Runx2, thus suppressing their induction of the osteocalcin (Ocn) gene and phosphatase activity (103). This negative modulation is also supported by recent experiments. Osteoblast proliferation 
and differentiation can be regulated by ADP-ribosylation-like factor 6 interacting protein 5 (Arl6ip5), whereas CHOP is required for reduction of the above two events and induces apoptosis in Arl6ip5-knockdown osteoblasts (104). The promotion of osteoblast differentiation by the transcription factor EB is coupled with reduced expression of ATF4 and CHOP. However, their expression was upregulated by TFEB overexpression in the stimulation of bone morphogenic protein 2 (BMP2), a potent inducer of osteoblast differentiation (105). It was previously proposed that $\mathrm{CHOP}$ may indirectly promote BMP2-induced osteogenesis (103) and enhance osteoblast differentiation of mesenchymal progenitor cells especially in the presence of BMP2 (106). Consistent with the finding, the PERK-eIF2 $\alpha-$ ATF4 pathway promotes BMP2-induced osteoblast differentiation (107). Taken together, expression of CHOP exerts a dual role in osteoblast differentiation. It may be that the inhibitory action of $\mathrm{CHOP}$ is not sufficient to affect BMP2-induced differentiation processes. The specific association between CHOP and BMP2 in osteoblasts remains a topic of further exploration. Moreover, myoblast differentiation is inhibited by CHOP, which suppresses the transcription of myogenic regulatory factor in myoblasts by binding to its transcription regulatory sequences and affecting histone acetylation (108). Recent evidence has also unveiled that $\mathrm{CHOP}$ blocks the progression of myeloid lineage in granulomonocytic progenitors (109).

\section{CHOP IN DISEASES}

$\mathrm{C} / \mathrm{EBP}$ homologous protein has widely documented roles in metabolism, neurodegeneration, and therioma. Recent findings have added the condition of fibrosis to this list of diseases mediated by $\mathrm{CHOP}$. CHOP-mediated cellular apoptosis leads to organ dysfunction and may thus be involved in a wide range of diseases. We herein highlight recent advances that implicate CHOP in the occurrence, development, and outcome of diseases; in addition to outlining potential treatment strategies that target CHOP.

\section{Fibrosis}

Fibrosis progresses as an eventual pathological outcome of three stages of general wound-healing responses; injury, inflammation, and repair to persistent organ injury. A pathological hallmark of fibrosis is the excessive deposition of extracellular matrix (ECM) in the tissues. This increased protein synthesis may disturb ER homeostasis and induce the expression of CHOP (110). An emerging role of $\mathrm{CHOP}$ in promoting fibrotic response of internal organs is supported by alleviation of fibrosis in CHOP-knockout mice (111). Given that apoptosis is a common cellular event that leads to organ remodeling and fibrosis after insult, CHOP-initiated pro-apoptotic activity may be partly the underlying mechanism. Moreover, alternatively activated phenotype (M2) macrophages are considered to participate in promoting collagen deposition and fibrogenesis. In recent years, research advances have indicated that $\mathrm{CHOP}$ likely regulates the activation of M2 macrophages to trigger tissue fibrosis (112). These M2 macrophages would release various cytokines to create a microenvironment that favors fibrogenesis, including high levels of TGF- $\beta 1$, which is a key factor that promotes the activation of ECM-producing myofibroblasts (113). Modulation of CHOP expression may be a potential treatment for organ fibrosis. Here, we show the vital role of $\mathrm{CHOP}$ in the formation of specific fibrotic disorders.

\section{Lung Fibrosis}

The crucial events in the pathogenesis of lung fibrosis include TGF- $\beta$ activation and alveolar epithelial cells (AECs) apoptosis, which then trigger resident fibroblast proliferation and differentiation of ECM-producing myofibroblasts (114). Research in the past decade has established a relation between ER stress and lung fibrosis (115). CHOP, the key player in ER stress, was found to mediate methamphetamine (MA) and thrombin-induced apoptosis of AECs in chronic pulmonary injury or fibrotic lung tissue $(116,117)$. Likewise, analysis of lung tissue from mouse fibrosis models induced by bleomycin (BLM) and from patients with IPF has manifested altered CHOP expression along with ER stress. Indeed, the loss of CHOP expression protected mice from BLMinduced pulmonary injury and fibrosis $(112,118)$. Mechanistic investigation indicates that $\mathrm{CHOP}$ regulates the production of M2 macrophages and subsequent TGF- $\beta 1$ signaling involved in lung fibrosis. Further studies dissected the mechanism through which $C H O P$ deficiency reduced M2 macrophage infiltration, for it upregulated the STAT6 inhibitors SOCS1 and SOCS3, thus repressing STAT6/PPAR- $\gamma$ signaling (112). Meanwhile, a different viewpoint has been posited that $\mathrm{CHOP}$-mediated macrophage apoptosis provides protection for $G r p 78^{+/-}$mice against BLMinduced fibrosis (119). Nevertheless, both of these competitive findings support the role of $\mathrm{CHOP}$ in regulating macrophage to participate in the progress of lung fibrosis.

\section{Kidney Fibrosis}

Renal fibrosis, which includes glomerulosclerosis and/or tubulointerstitial fibrosis, is a common pathogenic consequence of chronic progressive renal diseases. Overwhelming expression of ER stress markers including CHOP are associated with fibrosis in rat kidneys subjected to unilateral ureteral obstruction (UUO) (120). Zhang and colleagues first noted that $\mathrm{CHOP}^{-/-}$mice were protected from UUO-induced renal fibrosis, wherein loss of CHOP decreased UUO-induced apoptosis of tubular cells and the Hmgb1/TLR4/NFkB/IL-1 $\beta$ signaling. Thus, the IL- $1 \beta$ downstream TGF- $\beta 1 / \mathrm{Smad} 2 / 3$ signaling was also inhibited, eventually ameliorating renal fibrosis (121). Consistent results were also obtained that indicate that $C H O P$ deletion attenuated renal tubulointerstital fibrosis in the mouse UUO model. In addition, there are novel findings about these mechanisms that $\mathrm{CHOP}$ deficiency not only lessens tubular cell apoptosis but also abates profibrotic factors, oxidative stress, and recruitment of inflammatory cells including macrophages (111). Recently, both in patients with renal fibrosis resulting from chronic kidney disease (CKD) and a mouse fibrosis model of hypertensive CKD, an increase in $C H O P$ gene was demonstrated. Furthermore, inhibition of CHOP by an ER stress inhibitor, 4-phenylbutyric acid, attenuated renal interstitial fibrosis, as well as macrophage infiltration and TGF $\beta 1$ expression. CHOP-knockout mice developed less renal fibrosis accompanied by lower macrophage infiltration (122). Moreover, 
Pan et al. found that M2 macrophages specifically enhance epithelial-to-mesenchymal transition and subsequent renal fibrosis by high production of TGF $\beta 1$ in a mouse UUO model (113). In addition, a function of CHOP in inducing fibronectin production in tubule cells was identified, indicating its role in promoting tubulointerstitial fibrosis during diabetic nephropathy (DN) (123).

\section{Liver Fibrosis}

Hepatic stellate cells (HSCs) are the principal cell-type responsible for ECM production and collagen deposition during liver fibrogenesis in which it is activated into myofibroblast in a TGF- $\beta 1$-dependent manner. An early study on hepatic fibrosis in cholestatic liver injury caused by bile duct ligation showed that CHOP deletion alleviated hepatocyte death and hepatic fibrosis, with inhibitory effect on TGF- $\beta 1$ induction and HSCs activation (124). CHOP deficiency also attenuated liver fibrosis in HCC induced by diethylnitrosamine (DEN) (125), and a fat-loading, methionine-choline-deficient diet (126). As illustrated by the aforementioned studies, hepatocyte apoptosis is a cellular mechanism underlying the promotion of CHOP for hepatic fibrotic response (127). Moreover, $\mathrm{CHOP}$ was significantly upregulated in the liver from animals with $\mathrm{CCl}_{4}$-induced fibrosis (128). Another study showed that pronounced CHOP expression was stimulated by hepatitis B virus (HBV) surface proteins and correlated with increased liver injury and fibrosis in $\mathrm{HBV}$ transgenic mice on $\mathrm{BALB} / \mathrm{c}$ background, as compared to C57BL/6 (129). Ablation of $\mathrm{CHOP}$ attenuated hepcidin suppression and ensuing iron overload in a mouse liver fibrosis model induced by thioacetamide (130). In contrast, liver fibrosis induced by dietary steatohepatitis was greater in $\mathrm{CHOP}^{-/-}$mice, due to lessened $\mathrm{CHOP}$-induced apoptosis of activated macrophages (131).

Taken together, in both mouse renal fibrosis and pulmonary fibrosis models, the deletion of the CHOP gene resulted in a marked decrease in inflammatory infiltration of macrophages, embodying a reduced differentiation of M2 macrophages, which are considered as a new cell-type involved in fibrogenesis. To the best of our knowledge, no studies have yet found that CHOP can regulate M2 macrophages in hepatic fibrosis, while it has been verified that M2 macrophages play an important role in schistosomiasis-induced liver fibrogenesis via IL-13/STAT6 signaling pathways (132). Hepatic fibrosis during schistosomiasis may represent a class of special cases where macrophage is actively involved in host immune responses against schistosome infection. Macrophages have long been accepted as profibrotic in schistosome infection. However, there are reports showing that restorative macrophages, characterized by an anti-inflammatory anti-fibrogenic expression profile, are in fact key to the remodeling and resolution of liver fibrosis $(133,134)$. Therefore, further studies investigating the role of CHOP in different macrophage subsets during liver fibrosis may advance our understanding of the involvement of CHOP in liver fibrosis.

\section{Cardiac Fibrosis}

It has also been suggested that CHOP may be involved in cardiac myocyte apoptosis, cardiac hypertrophy, and heart failure (135, 136). A high-fat diet fed to metabolically healthy, obese minipigs activates oxidative stress and ER stress with increasing expression of CHOP in myocardial fibrosis within the minipigs (137). In mice subjected to a transverse aortic constriction operation, ablation of CHOP can attenuate cardiac hypertrophy, cardiac dysfunction, and fibrosis with less apoptotic cell death (138) and alleviate myocardial reperfusion injury via attenuated myocardial apoptosis and inflammation (139).

\section{Cancer}

In states of uncontrolled proliferation and insufficient vascularization (e.g., in cancer), conditions of low nutrient supply, such as hypoxia and oxidative stress, may trigger ER stress and subsequent UPR activation that have been documented in various human cancers (140). Studies have shown evidence of CHOP activation in various types of cancer cells $(125,141)$. Thus, CHOP-induced apoptosis in ER stress has significant implications for cancers. Furthermore, $\mathrm{CHOP}$ mutations are found in some human tumors, although whether or not they contribute to tumorigenesis remains unknown (142). Accumulating data suggest that CHOP impinges upon several aspects of cancer including tumor formation as well as progression of tumors once formed. Nonetheless, how $\mathrm{CHOP}$ activation exerts tumor-supporting or tumor-suppressive roles remains to be elucidated.

\section{The Role of CHOP in Carcinogenesis}

Most of the evidence supports an anti-oncogenic function of CHOP-induced apoptosis in a stressful environment. Indeed, apoptosis is a critical mechanism for maintaining tissue homeostasis through selective elimination of cells once they are damaged, mutated, or pose a threat to the organism, such as precancerous cells. During stress conditions, the human hematopoietic stem cell (HSC) pool maintains integrity by elimination of individual HSCs through PERK-eIF2 $\alpha-A T F 4-C H O P-G A D D 34$ signaling induced apoptosis, hence preventing persistent cloning of oncogenic mutations and decreasing the risk of leukemogenesis (73). $\mathrm{CHOP}$ induction triggers apoptosis of premalignant cells to prevent malignant progression in a mouse lung cancer model (143). Hepatocyte-specific CHOP ablation increased tumorigenesis in high fat diet-induced steatohepatitis and HCC. This effect indicates a tumor-suppressive role of CHOP, perhaps via apoptosis of initiated hepatocytes in preneoplastic lesions (144). However, $\mathrm{CHOP}$ tends to promote specific oncogenic processes, at least in one case; when fused with FUS/TLS or EWS protein by genomic rearrangement $(145,146)$. The FUS-CHOP oncoprotein has been newly proved to induce metastasis via transcriptional induction of tumor-associated proteases, both in liposarcoma and fibrosarcoma cell lines, as well as an in vivo model (147). Specifically, DeZwaan-McCabe et al. (125) proposed that ISR-induced CHOP provokes inflammation and fibrosis followed by compensatory proliferation to promote chemical hepatocarcinogenesis (148). $\mathrm{CHOP}$ was upregulated both in genetic and DEN-induced mouse models of HCC, as well as human HCC. $\mathrm{CHOP}^{-/-}$mice were protected from DEN-induced oncogenesis in liver, which was also proven by Scaiewicz et al. (149). The latter further found a marked reduction of IFN $\gamma$ levels and macrophages in CHOPknockout tumors and ATF6 activation upstream of CHOP, implying that $\mathrm{CHOP}$ induction regulates inflammation and 
macrophage infiltration to promote hepatocarcinogenesis after DEN treatment. In actuality, the carcinogen DEN evokes DNA damage and the apoptosis induced by this damage partly contributes to chronic inflammation and release of tumor-promoting cytokines. Collectively, CHOP may play an anti-oncogenic role in the precancerous cells and an oncogenic role when expressed in macrophages.

\section{CHOP in Cancer Development and Progression}

During the progression of tumors, CHOP triggers the death of a number of tumor cells, which has been reviewed (3). In the case of hepatoma cells, CHOP mediates the autophagic apoptosis induced by apoptosis-stimulating protein of p53-2 (150). However, the tumor-supporting functions of CHOP have been newly indicated in certain cells. Thevenot et al. found that the MDSC with immunosuppressive activity within tumors aberrantly expressed $\mathrm{CHOP}$ without completely undergoing apoptosis. $\mathrm{CHOP}$ deficiency induced antitumor effects in a MDSC-dependent manner, suggesting an important role of $\mathrm{CHOP}$ in tumor tolerance and potential benefits of its inhibition for tumor immunotherapy (88, 151). Moreover, SPOP mutations fail to mediate CHOP degradation and suppress CHOP-induced apoptosis, which indicates $\mathrm{CHOP}$ involvement in the progression of prostate cancer is associated with SPOP mutations (9). A common hallmark of a tumor microenvironment is hypoxia, during which cancer cells can activate pathways to develop and progress, such as immune responses. CHOP expression, in the context of ER stress and TLR agonists, increases dendritic cell expression of IL-23 (152), which supports $\mathrm{T}$ helper 17 cell propagation and its function to promote immune response and tumor growth (153). Induction of autophagy by ATF4 and CHOP helps several human cancer cell lines adapt to hypoxia (96), whereas a previous study suggests that cyclophilin B mediates the adaptation of tumor cells to hypoxia through ubiquitin-dependent degradation of CHOP (154). Overall, further understanding of the pro- and anti-oncogenic roles of CHOP and information on the cell types where CHOP is activated or suppressed in different stages of cancer may provide insight into different carcinogenesis modalities and promote its implication for cancer therapy.

\section{CHOP in Cancer Therapy}

Here, we also highlight recent advances in therapeutic strategies for cancer treatment that involve CHOP. CHOP-induced cell death has been widely suggested as one of the strategies to ameliorate cancer (Table 1). First, experiments with cancer cells have demonstrated that CHOP-mediated DR5 expression is responsible for the caspase8-mediated apoptotic pathway (70). Therefore, various natural and synthetic products that enhance CHOP-DR5 signaling have been presented for treatment of a series of cancers $(45,71)$. Second, a selective CHOP inducer, sulfonamidebenzamide, was identified with pro-apoptotic and antiproliferative effects in multiple cancer cell lines (155). Asparagine was found as a CHOP inhibitor with anti-apoptotic function, and suppression of asparagine synthetase may restore $\mathrm{CHOP}$-induced cell death and exert therapeutic benefit in solid tumors (156). Finally, CHOP forms a complex with C/EBP $\beta$ and decreases C/ EBP $\beta$-dependent ALDH1A3 expression in chemoresistant cell subpopulations. This mechanism may be responsible for buteininduced enhancement of chemoresistant cell apoptosis (157) and contributes to the treatment of non-small cell lung cancer with garcinol (158). The suppression of STAT3-NFkB activity by butein is a prerequisite for high levels of CHOP expression (157). Moreover, CHOP downregulated the anti-apoptotic $\mathrm{p} 21$ in cancer cells treated with TUN, thus enhancing chemotherapeutic drug efficacy (86). During radiotherapy with high-LET carbon ions, chloroquine co-treatment enhances apoptosis via IRE1-CHOP signaling in vitro and in vivo (159). Besides apoptosis, CHOP regulated androgen receptor degradation in prostate cancer cells treated with rosemary extract (160). All types of oncogenic FUS-CHOP fusion proteins can be inactivated by trabectedin through blockage of their binding to target promoters, both in a mice xenograft model and human cell lines, thereby exerting a selective antitumor activity (161).

\section{Diabetes}

In diabetes mellitus, the glucostatic cycle to maintain normoglycemia is dysregulated due to an insufficient mass of functioning pancreatic $\beta$-cells to synthesize the needed amounts of insulin for metabolism (162). For type 2 diabetes (T2D), insulin resistance under stress of excess nutrients, including hyperglycemia and hyperlipemia, causes progressive $\beta$-cell failure (163). Dissimilarly, in type 1 diabetes (T1D), $\beta$-cells are attacked by autoimmune activity and the workload of the remaining $\beta$-cells increases. Collectively, high demand of insulin synthesis and secretion overwhelms the capacity of $\beta$-cell ER and thereby activates UPR to compensate. As the process continues, terminal UPR leads to apoptosis of $\beta$-cells and the onset of diabetes (164).

Apoptosis has been the main focus of studies on $\beta$-cell dysfunction during diabetes, among which CHOP-induced apoptosis is the most studied, as it is a key event in the pathogenesis of diabetes (165). Indeed, numerous studies have found that islet cells from mice and patients with T1D or T2D manifests elevated levels of CHOP $(7,166)$. In 2002, studies conducted with Akita mice proved that genetic removal of $\mathrm{CHOP}$ alleviated $\beta$-cell loss and hereditary diabetes, which vividly links $\mathrm{CHOP}$ to $\beta$-cell apoptosis for the first time (167). CHOP deficiency also prevents oxidative damage with reduced ROS and thereby improves ER function in $\beta$-cells (168), while oxidative stress is proven as an important factor that gives rise to $\beta$-cell dysfunction in diabetes (169). Thus, past studies have identified drugs, such as vildagliptin (170), that promote $\beta$-cell survival by decreasing $\mathrm{CHOP}$ expression in diabetic mouse models, along with downregulation of ATF4 and TRIB3 in T2D db/db mice (171).

For T2D, it has been evidenced that CHOP is responsible for $\beta$-cell apoptosis and dysfunction both in genetic and diet-induced mouse models of T2D, as well as in vitro $(168,172)$. The PERK/ eIF2 $\alpha /$ CHOP signaling mediated $\beta$-cell sensitization to lipotoxicity and apoptosis under the challenge of palmitate $(173,174)$ and guanabenz (175). Ubiquitination and degradation of CHOP by cellular inhibition of apoptosis protein-1 prevented palmitateinduced lipotoxicity (173). Consistent with this notion, the inhibition effect of CHOP on adipocyte differentiation interferes with effective fatty acid storage, which may cause lipotoxicity. Furthermore, the human islet amyloid polypeptide (h-IAPP), 
TABLE 1 | Strategies to target C/EBP homologous protein (CHOP)-mediated cell death for cancer treatment in preclinical models.

\begin{tabular}{|c|c|c|c|c|}
\hline Cancer type & Treatment agents & Involved mechanisms and phenotype & Research models & Reference \\
\hline Pancreatic cancer & CGK733 & $\begin{array}{l}\text { Induces calcium sequestration in reversible vesicles through PRKR- } \\
\text { like ER kinase (PERK)-CHOP signaling and subsequent non- } \\
\text { apoptotic/necrotic cell death }\end{array}$ & Cells & $(207)$ \\
\hline \multirow[t]{2}{*}{ Hepatocellular carcinomas } & IMB-6G & $\begin{array}{l}\text { Induces mitochondrial-dependent apoptosis via PERK-CHOP } \\
\text { signaling } \\
\text { Induces IRE1 } \alpha \text {-ASK1-JNK mediated apoptosis }\end{array}$ & Cells & $(208)$ \\
\hline & Piperlongumine & $\begin{array}{l}\text { Increases reactive oxygen species (ROS) and activates endoplasmic } \\
\text { reticulum (ER)-mitogen-activated protein kinases (MAPKs)-CHOP } \\
\text { signaling in vivo and in vitro to trigger cell death } \\
\text { Suppresses migration/invasion }\end{array}$ & Cells, mice (xenografts) & $(43)$ \\
\hline Triple-negative breast cancer & $\begin{array}{l}\text { YM155 (surviving } \\
\text { suppressant) }\end{array}$ & $\begin{array}{l}\text { Upregulates p38 mitogen-activation protein kinase (p38 MAPK)- and } \\
\text { CHOP-mediated DR5 expression to induce apoptotic response } \\
\text { Impairs cell growth and increases cytotoxic effect }\end{array}$ & Cells, mice & $(209)$ \\
\hline Non-small cell lung cancer & Obovatol & Activates CHOP-induced apoptosis & Cells & $(210)$ \\
\hline & Licochalcone A & Induces CHOP-dependent apoptosis and autophagy & Cells & $(94)$ \\
\hline Ovarian carcinoma & Tanshinone IIA & Activates extrinsic apoptosis by JNK-CHOP-DR5 signaling & Cells & $(44)$ \\
\hline Colon carcinoma & Apigenin & $\begin{array}{l}\text { Activates } \mathrm{CHOP} \text {-mediated intrinsic and extrinsic apoptotic pathways } \\
\text { with } \mathrm{ROS} \text { generation and } \mathrm{Ca}^{2+} \text { release } \\
\text { Exerts anti-proliferation and cell cycle arrest role }\end{array}$ & Cells & $(211)$ \\
\hline Colorectal cancer & $\begin{array}{l}\text { Rapalogs and ATP- } \\
\text { competitive mTOR } \\
\text { inhibitors }\end{array}$ & Activates CHOP-DR5 axis-dependent extrinsic apoptosis pathway & Cells & $(212)$ \\
\hline Multiple myeloma & $\begin{array}{l}\text { Histone deacetylase } 4 \\
\text { inhibitor }\end{array}$ & $\begin{array}{l}\text { Activates activating transcription factor (ATF)4-CHOP-induced } \\
\text { apoptosis } \\
\text { Enhances the cytotoxicity of ER stressor }\end{array}$ & Cells, mice & $(213)$ \\
\hline $\begin{array}{l}\text { T-cell lymphoblastic lymphoma } \\
\text { and T-cell acute lymphoblastic } \\
\text { leukemia }\end{array}$ & LAT1 selective inhibitor & $\begin{array}{l}\text { Induces ATF6, ATF4, elF2 } \alpha \text {, growth arrest and DNA-damage- } \\
\text { inducible protein 34, p38 MAPK expression and triggers CHOP- } \\
\text { dependent apoptosis } \\
\text { Decreases activation of Akt and mTORC1 } \\
\text { Decreases cell viability and proliferation }\end{array}$ & Cells, mice (xenografts) & $(214)$ \\
\hline $\begin{array}{l}\text { T-cell acute lymphoblastic } \\
\text { leukemia }\end{array}$ & Inhibitor of $\mathrm{CK} 2 \alpha$ & $\begin{array}{l}\text { Activates apoptosis induced by IRE } 1 \alpha \text { and } \mathrm{CHOP} \\
\text { Downregulates PI3K/Akt/mTOR signaling and the levels of GRP78 } \\
\text { Exerts cytotoxic and cytostatic effects }\end{array}$ & Cells & $(215)$ \\
\hline Oral squamous cell carcinoma & Celastrol & Induces cell death through PERK-elF2-ATF4-CHOP signaling & $\begin{array}{l}\text { Cells, murine embryonic } \\
\text { fibroblasts }\end{array}$ & $(216)$ \\
\hline Human esophageal cancer & $\begin{array}{l}\text { Neddylation inhibitors } \\
\text { (MLN4924) }\end{array}$ & $\begin{array}{l}\text { Induces ATF4-CHOP-DR5-mediated extrinsic apoptosis } \\
\text { Triggers ATF4-Noxa axis-mediated intrinsic apoptosis }\end{array}$ & Cells, murine & $(72)$ \\
\hline Glioblastoma multiform & Isochaihulactone & Induces CHOP-NAG1-mediated apoptosis independent of PERK & Cells, mice (xenografts) & $(217)$ \\
\hline
\end{tabular}

also characteristic of $\mathrm{T} 2 \mathrm{D}$, induced dysfunction of autophagy and apoptosis through $\mathrm{CHOP}$, but inhibition of $\mathrm{CHOP}$ alone may not be a durable therapeutic strategy for the $\beta$-cell toxicity of h-IAPP, considering multiple stress pathways are activated during this process (176). To unveil the specific mechanisms underlying $\beta$-cell apoptosis in $\mathrm{T} 2 \mathrm{D}$, researchers found that $\mathrm{CHOP}$ regulation of puma is essential for the apoptotic pathway during glucotoxicity T2D (177). Another critical event is that CHOP downregulates p21 to trigger $\beta$-cell apoptosis due to glucotoxicity, thus promoting the onset of T2D $(85,178)$. As such, the chemicals that inhibit $\mathrm{CHOP}$ expression protect $\beta$ cells from apoptosis and dysfunction, such as 1,2,3-triazole derivatives (179).

For insulinopenic T1D, autoimmunity triggers an inflammatory response along with cytokine release which induces ER stress in $\beta$-cells. CHOP contributes to cytokine-induced apoptosis of $\beta$-cells via mitochondrial apoptotic pathways and indirect pro-inflammatory responses, indicating the role of $\mathrm{CHOP}$ in T1D. Mechanistic studies have shown that CHOP knockdown in insulinoma cell lines protected against the downregulation of anti-apoptotic BCL-2-like proteins, Bcl-2 and Mcl-1, while decreasing NF- $\mathrm{KB}$ activity and expression of its target genes, including inducible NO synthase (iNOS) and TNF receptor superfamily member 6 (FAS) (180). CHOP blocking by siRNA partially protected human beta cells against cytokine-induced apoptosis independent of $\mathrm{NO}$, whereas $\mathrm{CHOP}$ induction was $\mathrm{NO}$ dependent and could be inhibited by iNOS blocker in rat insulinproducing cells (181). Moreover, CHOP acted as a mediator of $\beta$-cell apoptosis in islets deficient for Gata4, which belongs to a group of $\beta$-cell survival factors that contribute to T1D risk when they undergo mutations (182).

Overall, cumulating evidence suggests that $\mathrm{CHOP}$ is involved in the pathogenesis of diabetes, predominantly $\mathrm{T} 2 \mathrm{D}$, in response 
to glucotoxicity, lipotoxicity, as well as oxidative stress and islet amyloid derived from IAPP. With regard to diabetic complications, there is also some relevance to CHOP. For example, during murine DN, ATF6-dependent CHOP activation was induced by defective insulin signaling due to impaired nuclear translocation of sXBP1 in podocytes (34), whereas CHOP-null mice gained protection from DN (183). Tubules of diabetic mice and patients showed increased levels of CHOP protein, and other than apoptosis, CHOP-induced expression of fibronectin in tubule cells (123). As for diabetic cardiovascular complications, including diabetic cardiomyopathy, IL- $1 \beta$-induced myocyte apoptosis was mediated by the IRAK-2/CHOP pathway (184). CHOP-induced apoptosis was partly targeted by Ginsenoside Rg1 to ameliorate diabetic myocardial damage (185). Correspondingly, myocyte apoptosis and cardiac dysfunction induced by methylglyoxal were attenuated in CHOP-null mice (62). Furthermore, streptozotocin-induced diabetic $\mathrm{CHOP}^{-/-}$mice manifested not only reduced hyperglycemia but also lessened severity of oxidativenitrative stress in their sciatic nerve and in their eventual diabetic peripheral neuropathy (186).

\section{Neurodegeneration}

Neurodegenerative diseases are hallmarked by progressive loss of neuronal function. Many risk factors including aging, oxidative stress, and gene mutations of neurodegenerative process can cause toxic accumulation of misfolded proteins, which ultimately leads to neuronal cells undergoing ER stress-induced apoptosis. As a key player in ER stress and oxidative stress, CHOP expression is found to be elevated in many disorders related to neurodegeneration, such as the Parkinson disease (PD) (187), and $\mathrm{CHOP}$ induces neuronal apoptosis, which has been proposed as a target of treatments for some neurodegenerative diseases (188). In some cases, disruption of CHOP exerts a neuroprotective role through yet unknown mechanisms (189). We list here important studies on CHOP involvement in neurodegenerative diseases in recent years.

A prominent clinical hallmark of Alzheimer's disease (AD) is progressive cognitive impairment. $\mathrm{AD}$ is attributed to pathological deposits of neurofibrillary tangles formed by hyperphosphorylated tau aggregates and abnormal aggregation of amyloid- $\beta$ $(\mathrm{A} \beta)$ plaques. In the $\mathrm{AD}$ brain, ATF4 synthesis in axons locally exposed to $A \beta_{1-42}$ triggered retrograde cell loss through $\mathrm{CHOP}$, and conversely, $C H O P$ deletion hindered $A \beta_{1-42}$-mediated neurodegeneration (190). In the mouse model of AD and neuroblastoma cells, researchers analyzed the effect of palmitate and noticed that $\mathrm{CHOP}$ indispensably mediated increased $\beta$-site APP-cleaving enzyme 1 (BACE1) activity and ensuing A $\beta$ production, but only partially (191). In agreement with this, silencing $\mathrm{CHOP}$ expression attenuated NF- $\mathrm{\kappa B}$ activation and its binding to the BACE1 promoter, thus reducing $A \beta$ production induced by 27-hydroxycholesterol (192). CHOP knockdown also alleviated the negative regulation of $\mathrm{C} / \mathrm{EBP} \alpha$ binding to the leptin promoter and subsequent leptin expression, which is able to decrease $A \beta$ genesis and tau phosphorylation (193). As for PD, CHOP and ATF4 play a key role in regulating Trib3 and apoptosis in cellular models of $\mathrm{PD}$, as evidenced by the protective role of $\mathrm{CHOP}$ and ATF4 knockdown in 6-OHDA and MPP(+) models (194). Inhibition of CHOP-mediated crocin-induced neuroprotection in the PD model through Wnt pathway in vitro (195).

In S63-deletion mice of Charcot-Marie-Tooth (CMT) disease type $1 \mathrm{~B}, C H O P$ deletion decreased demyelination and rescued their motor deficit (196). Mechanistic studies subsequently revealed that $\mathrm{CHOP}$ targeted GADD34 to reactivate translation in the nerves of this model (197). Surprisingly, CHOP ablation did not rescue the abnormalities of Schwann cell development in R98C mouse model of type 1B CMT (198). Prion-related diseases are another type of neurodegenerative disorder, and accumulation of prion protein (PrP) defines the pathobiology. Upregulation of CHOP through the PERK pathway is a pathogenic factor of neurodegeneration induced by the membrane-tethered flexible tail of PrP (199). A role of CHOP in mild spinal cord injury is indicated by enhanced neuronal functional recovery in CHOP-deficient mice, partly due to decreased oligodendrocyte apoptosis (200). Moreover, CHOP and caspase12 induced neuron apoptosis at later stages of chemical hypoxia (201). In the context of neurodegeneration in retinas, a sustained upregulation of CHOP can result from optic nerve injury and $C H O P$ deficiency increased the survival of retinal ganglion cells (202). Apoptotic cell death of photoreceptors was also mediated by $\mathrm{CHOP}$ in retinas deficient in autophagosomes (203). Likewise, in brain astrocytes, MA mediated CHOP upregulation downstream of the activation of all three ER stress pathways, which together lead to apoptosis via intrinsic caspase cascade (204). This arises as the mechanism of MA-mediated neurodegenerative effects. The PERK-eIF $2 \alpha-$ ATF4-CHOP pathway mediated sevoflurane-induced neuroapoptosis in neonatal brains (205). Moreover, CHOP expression in the brain plays a pivotal role in the negative regulation of two neurotrophic cytokines, leptin and insulin-like growth factor-1 by palmitate (206).

\section{SUMMARY AND PERSPECTIVES}

In summary, induction of $\mathrm{CHOP}$ is converged from the regulation of UPR, ISR, and MAPKs signaling in response to various cellular stress conditions, including ER stress and ROS. CHOP can be protective for cell survival via regulating autophagy in early stages (before irreversible ER stress). This stress-responsive transcription factor has been extensively recognized as the link between prolonged protein-folding stress, namely ER stress and apoptosis. To the best of our knowledge, no studies have yet shown that $\mathrm{CHOP}$ directly leads to apoptosis. $\mathrm{CHOP}$ indirectly regulates apoptosis by controlling the expression of pro-apoptotic or antiapoptotic genes. Therefore, we have constructed a signal network depicting canonical and emerging targets of the CHOP-dependent apoptotic pathway, including the BCL-2-mediated intrinsic and DR5-mediated extrinsic apoptotic pathway. Collectively, they can result in protein aggregation, disturbance of redox status, and mitochondrial function to culminate in apoptosis. Inhibition of $\mathrm{CHOP}$ is an approach to improve the survival and function of cells. However, in certain conditions, CHOP expression does not induce cell apoptosis. Given the dual role of $\mathrm{CHOP}$, whether it is 
more a pro-apoptotic or a protective factor remains to be defined in specific cell types. Cells behave differently to CHOP induction owing to the intensity and duration of stress, as well as distinct cell and disease context.

$\mathrm{C} / \mathrm{EBP}$ homologous protein impinges upon different process such as autophagy, apoptosis, and cell differentiation. From an overview of its impact on different diseases so far, apoptosis is a major cellular function of CHOP that involves it in pathological processes for a wide range of diseases. CHOP-dependent apoptosis may exert amelioration or aggravation effects on different diseases. It has been increasingly implicated as a treatment strategy in the context of cancer and more in vivo research is needed to evaluate the efficacy. In addition, the emerging roles of $\mathrm{CHOP}$ in the progress of fibrosis and regulation of macrophage polarization open up new avenues for future research. The

\section{REFERENCES}

1. Oyadomari S, Mori M. Roles of CHOP/GADD153 in endoplasmic reticulum stress. Cell Death Differ (2004) 11(4):381-9. doi:10.1038/sj.cdd.4401373

2. Bruhat A, Jousse C, Wang XZ, Ron D, Ferrara M, Fafournoux P. Amino acid limitation induces expression of CHOP, a CCAAT/enhancer binding protein-related gene, at both transcriptional and post-transcriptional levels. J Biol Chem (1997) 272(28):17588-93. doi:10.1074/jbc.272.28.17588

3. Li Y, Guo Y, Tang J, Jiang J, Chen Z. New insights into the roles of CHOPinduced apoptosis in ER stress. Acta Biochim Biophys Sin (Shanghai) (2014) 46(8):629-40. doi:10.1093/abbs/gmu048

4. Way SW, Popko B. Harnessing the integrated stress response for the treatment of multiple sclerosis. Lancet Neurol (2016) 15(4):434-43. doi:10.1016/ s1474-4422(15)00381-6

5. Pakos-Zebrucka K, Koryga I, Mnich K, Ljujic M, Samali A, Gorman AM. The integrated stress response. EMBO Rep (2016) 17(10):1374-95. doi:10.15252/ embr.201642195

6. Hetz C, Chevet E, Harding HP. Targeting the unfolded protein response in disease. Nat Rev Drug Discov (2013) 12(9):703-19. doi:10.1038/nrd3976

7. Wang M, Kaufman RJ. Protein misfolding in the endoplasmic reticulum as a conduit to human disease. Nature (2016) 529(7586):326-35. doi:10.1038/ nature17041

8. Oakes SA, Papa FR. The role of endoplasmic reticulum stress in human pathology. Annu Rev Pathol (2015) 10:173-94. doi:10.1146/ annurev-pathol-012513-104649

9. Zhang P, Gao K, Tang Y, Jin X, An J, Yu H, et al. Destruction of DDIT3/CHOP protein by wild-type SPOP but not prostate cancer-associated mutants. Hum Mutat (2014) 35(9):1142-51. doi:10.1002/humu.22614

10. Dai X, Ding Y, Liu Z, Zhang W, Zou MH. Phosphorylation of CHOP (C/ EBP homologous protein) by the AMP-activated protein kinase alpha 1 in macrophages promotes $\mathrm{CHOP}$ degradation and reduces injury-induced neointimal disruption in vivo. Circ Res (2016) 119(10):1089-100. doi:10.1161/ circresaha.116.309463

11. Wang XZ, Ron D. Stress-induced phosphorylation and activation of the transcription factor CHOP (GADD153) by p38 MAP Kinase. Science (1996) 272(5266):1347-9. doi:10.1126/science.272.5266.1347

12. Devries-Seimon T, Li Y, Yao PM, Stone E, Wang Y, Davis RJ, et al. Cholesterolinduced macrophage apoptosis requires ER stress pathways and engagement of the type A scavenger receptor. J Cell Biol (2005) 171(1):61-73. doi:10.1083/ jcb. 200502078

13. Tsukada J, Yoshida Y, Kominato Y, Auron PE. The CCAAT/enhancer (C/EBP) family of basic-leucine zipper (bZIP) transcription factors is a multifaceted highly-regulated system for gene regulation. Cytokine (2011) 54(1):6-19. doi:10.1016/j.cyto.2010.12.019

14. Ubeda M, Wang XZ, Zinszner H, Wu I, Habener JF, Ron D. Stress-induced binding of the transcriptional factor CHOP to a novel DNA control element. Mol Cell Biol (1996) 16(4):1479-89. doi:10.1128/MCB.16.4.1479 broader functions and molecular mechanisms of $\mathrm{CHOP}$ in physiopathology will continue to be unveiled to target it in potential therapeutic strategies.

\section{AUTHOR CONTRIBUTIONS}

Each author has participated sufficiently in the work to take public responsibility for appropriate portions of the content.

\section{FUNDING}

This work was supported by grants from the National Natural Science Foundation of China (No. 81772223 and 81670431) and the Science and Technology Development Plan Project of Jingzhou, China (No. 2016AE51-5).

15. Ma Y, Brewer JW, Alan Diehl J, Hendershot LM. Two Distinct stress signaling pathways converge upon the $\mathrm{CHOP}$ promoter during the mammalian unfolded protein response. J Mol Biol (2002) 318(5):1351-65. doi:10.1016/ s0022-2836(02)00234-6

16. Matsumoto M, Minami M, Takeda K, Sakao Y, Akira S. Ectopic expression of CHOP (GADD153) induces apoptosis in M1 myeloblastic leukemia cells. FEBS Lett (1996) 395(2-3):143-7. doi:10.1016/0014-5793(96)01016-2

17. Maytin EV, Ubeda M, Lin JC, Habener JF. Stress-inducible transcription factor $\mathrm{CHOP} /$ gadd 153 induces apoptosis in mammalian cells via p38 kinase-dependent and -independent mechanisms. Exp Cell Res (2001) 267(2):193-204. doi:10.1006/excr.2001.5248

18. Ron D, Habener JF. CHOP, a novel developmentally regulated nuclear protein that dimerizes with transcription factors C/EBP and LAP and functions as a dominant-negative inhibitor of gene transcription. Genes Dev (1992) 6(3):439-53. doi:10.1101/gad.6.3.439

19. Su N, Kilberg MS. C/EBP homology protein (CHOP) interacts with activating transcription factor 4 (ATF4) and negatively regulates the stressdependent induction of the asparagine synthetase gene. J Biol Chem (2008) 283(50):35106-17. doi:10.1074/jbc.M806874200

20. Jauhiainen A, Thomsen C, Strombom L, Grundevik P, Andersson C, Danielsson A, et al. Distinct cytoplasmic and nuclear functions of the stress induced protein DDIT3/CHOP/GADD153. PLoS One (2012) 7(4):e33208. doi:10.1371/journal.pone.0033208

21. Puthalakath H, O’Reilly LA, Gunn P, Lee L, Kelly PN, Huntington ND, et al. ER stress triggers apoptosis by activating BH3-only protein Bim. Cell (2007) 129(7):1337-49. doi:10.1016/j.cell.2007.04.027

22. Yang X, Du T, Wang X, Zhang Y, Hu W, Du X, et al. IDH1, a CHOP and C/EBPbeta-responsive gene under ER stress, sensitizes human melanoma cells to hypoxia-induced apoptosis. Cancer Lett (2015) 365(2):201-10. doi:10.1016/j.canlet.2015.05.027

23. Han J, Back SH, Hur J, Lin YH, Gildersleeve R, Shan J, et al. ER-stress-induced transcriptional regulation increases protein synthesis leading to cell death. Nat Cell Biol (2013) 15(5):481-90. doi:10.1038/ncb2738

24. Luethy JD, Holbrook NJ. Activation of the gadd 153 promoter by genotoxic agents: a rapid and specific response to DNA damage. Cancer Res (1992) 52(1):5-10.

25. Yoshida H, Okada T, Haze K, Yanagi H, Yura T, Negishi M, et al. ATF6 activated by proteolysis binds in the presence of NF-Y (CBF) directly to the cis-acting element responsible for the mammalian unfolded protein response. Mol Cell Biol (2000) 20(18):6755-67. doi:10.1128/MCB.20.18.6755-6767.2000

26. Cherasse Y, Maurin AC, Chaveroux C, Jousse C, Carraro V, Parry L, et al. The p300/CBP-associated factor (PCAF) is a cofactor of ATF4 for amino acid-regulated transcription of CHOP. Nucleic Acids Res (2007) 35(17):5954-65. doi:10.1093/nar/gkm642

27. Gardner BM, Pincus D, Gotthardt K, Gallagher CM, Walter P. Endoplasmic reticulum stress sensing in the unfolded protein response. Cold Spring Harb Perspect Biol (2013) 5(3):a013169. doi:10.1101/cshperspect.a013169 
28. Ron D, Walter P. Signal integration in the endoplasmic reticulum unfolded protein response. Nat Rev Mol Cell Biol (2007) 8(7):519-29. doi:10.1038/ nrm2199

29. Fawcett TW, Martindale JL, Guyton KZ, Hai T, Holbrook NJ. Complexes containing activating transcription factor (ATF)/cAMP-responsive-element-binding protein (CREB) interact with the CCAAT/ enhancer-binding protein (C/EBP)-ATF composite site to regulate Gadd153 expression during the stress response. Biochem J (1999) 339(Pt 1):135-41. doi:10.1042/0264-6021:3390135

30. Korennykh A, Walter P. Structural basis of the unfolded protein response. Annu Rev Cell Dev Biol (2012) 28:251-77. doi:10.1146/ annurev-cellbio-101011-155826

31. Rozpedek W, Pytel D, Mucha B, Leszczynska H, Diehl JA, Majsterek I. The Role of the PERK/eIF2alpha/ATF4/CHOP signaling pathway in tumor progression during endoplasmic reticulum stress. Curr Mol Med (2016) 16(6):533-44. doi:10.2174/1566524016666160523143937

32. Hollien J, Weissman JS. Decay of endoplasmic reticulum-localized mRNAs during the unfolded protein response. Science (2006) 313(5783):104-7. doi:10.1126/science.1129631

33. Lee AH, Iwakoshi NN, Glimcher LH. XBP-1 regulates a subset of endoplasmic reticulum resident chaperone genes in the unfolded protein response. Mol Cell Biol (2003) 23(21):7448-59. doi:10.1128/MCB.23.21.7448-7459.2003

34. Madhusudhan T, Wang H, Dong W, Ghosh S, Bock F, Thangapandi VR, et al. Defective podocyte insulin signalling through $\mathrm{p} 85$-XBP1 promotes ATF6-dependent maladaptive ER-stress response in diabetic nephropathy. Nat Commun (2015) 6:6496. doi:10.1038/ncomms7496

35. Ye J, Rawson RB, Komuro R, Chen X, Dave UP, Prywes R, et al. ER stress induces cleavage of membrane-bound ATF6 by the same proteases that process SREBPs. Mol Cell (2000) 6(6):1355-64. doi:10.1016/S1097-2765(00)00133-7

36. Senkal CE, Ponnusamy S, Bielawski J, Hannun YA, Ogretmen B. Antiapoptotic roles of ceramide-synthase-6-generated C16-ceramide via selective regulation of the ATF6/CHOP arm of ER-stress-response pathways. FASEB J (2010) 24(1):296-308. doi:10.1096/f.09-135087

37. Baird TD, Wek RC. Eukaryotic initiation factor 2 phosphorylation and translational control in metabolism. Adv Nutr (2012) 3(3):307-21. doi:10.3945/ an. 112.002113

38. Harding HP, Zhang Y, Zeng H, Novoa I, Lu PD, Calfon M, et al. An integrated stress response regulates amino acid metabolism and resistance to oxidative stress. Mol Cell (2003) 11(3):619-33. doi:10.1016/S1097-2765(03)00105-9

39. Lozon TI, Eastman AJ, Matute-Bello G, Chen P, Hallstrand TS, Altemeier WA. PKR-dependent CHOP induction limits hyperoxia-induced lung injury. Am J Physiol Lung Cell Mol Physiol (2011) 300(3):L422-9. doi:10.1152/ ajplung.00166.2010

40. Michel S, Canonne M, Arnould T, Renard P. Inhibition of mitochondrial genome expression triggers the activation of $\mathrm{CHOP}-10$ by a cell signaling dependent on the integrated stress response but not the mitochondrial unfolded protein response. Mitochondrion (2015) 21:58-68. doi:10.1016/j. mito.2015.01.005

41. Guyton KZ, Xu Q, Holbrook NJ. Induction of the mammalian stress response gene GADD153 by oxidative stress: role of AP-1 element. Biochem J (1996) 314(Pt 2):547-54. doi:10.1042/bj3140547

42. Runchel C, Matsuzawa A, Ichijo H. Mitogen-activated protein kinases in mammalian oxidative stress responses. Antioxid Redox Signal (2011) 15(1):205-18. doi:10.1089/ars.2010.3733

43. Chen Y, Liu JM, Xiong XX, Qiu XY, Pan F, Liu D, et al. Piperlongumine selectively kills hepatocellular carcinoma cells and preferentially inhibits their invasion via ROS-ER-MAPKs-CHOP. Oncotarget (2015) 6(8):6406-21. doi:10.18632/oncotarget.3444

44. Chang CC, Kuan CP, Lin JY, Lai JS, Ho TF. Tanshinone IIA facilitates TRAIL sensitization by up-regulating DR5 through the ROS-JNK-CHOP signaling axis in human ovarian carcinoma cell lines. Chem Res Toxicol (2015) 28(8):1574-83. doi:10.1021/acs.chemrestox.5b00150

45. Trivedi R, Maurya R, Mishra DP. Medicarpin, a legume phytoalexin sensitizes myeloid leukemia cells to TRAIL-induced apoptosis through the induction of DR5 and activation of the ROS-JNK-CHOP pathway. Cell Death Dis (2014) 5:e1465. doi:10.1038/cddis.2014.429

46. Do MT, Na M, Kim HG, Khanal T, Choi JH, Jin SW, et al. Ilimaquinone induces death receptor expression and sensitizes human colon cancer cells to TRAIL-induced apoptosis through activation of ROS-ERK/p38 MAPKCHOP signaling pathways. Food Chem Toxicol (2014) 71:51-9. doi:10.1016/j. fct.2014.06.001

47. Gupta SC, Francis SK, Nair MS, Mo YY, Aggarwal BB. Azadirone, a limonoid tetranortriterpene, induces death receptors and sensitizes human cancer cells to tumor necrosis factor-related apoptosis-inducing ligand (TRAIL) through a p53 protein-independent mechanism: evidence for the role of the ROSERK-CHOP-death receptor pathway. J Biol Chem (2013) 288(45):32343-56. doi:10.1074/jbc.M113.455188

48. Lin JH, Li H, Yasumura D, Cohen HR, Zhang C, Panning B, et al. IRE1 signaling affects cell fate during the unfolded protein response. Science (2007) 318(5852):944-9. doi:10.1126/science.1146361

49. Ichijo H, Nishida E, Irie K, ten Dijke P, Saitoh M, Moriguchi T, et al. Induction of apoptosis by ASK1, a mammalian MAPKKK that activates SAPK/JNK and p38 signaling pathways. Science (1997) 275(5296):90-4. doi:10.1126/ science.275.5296.90

50. Darling NJ, Cook SJ. The role of MAPK signalling pathways in the response to endoplasmic reticulum stress. Biochim Biophys Acta (2014) 1843(10):2150-63. doi:10.1016/j.bbamcr.2014.01.009

51. Liu G, Su L, Hao X, Zhong N, Zhong D, Singhal S, et al. Salermide up-regulates death receptor 5 expression through the ATF4-ATF3-CHOP axis and leads to apoptosis in human cancer cells. J Cell Mol Med (2012) 16(7):1618-28. doi:10.1111/j.1582-4934.2011.01401.x

52. Liu Z, Shi Q, Song X, Wang Y, Song E, Song Y. Activating transcription factor 4 (ATF4)-ATF3-C/EBP homologous protein (CHOP) cascade shows an essential role in the ER stress-induced sensitization of tetrachlorobenzoquinone-challenged PC12 cells to ROS-mediated apoptosis via death receptor 5 (DR5) signaling. Chem Res Toxicol (2016) 29(9):1510-8. doi:10.1021/acs. chemrestox.6b00181

53. Yamazaki T, Ohmi A, Kurumaya H, Kato K, Abe T, Yamamoto H, et al. Regulation of the human CHOP gene promoter by the stress response transcription factor ATF5 via the AARE1 site in human hepatoma HepG2 cells. Life Sci (2010) 87(9-10):294-301. doi:10.1016/j.lfs.2010.07.006

54. Averous J, Bruhat A, Jousse C, Carraro V, Thiel G, Fafournoux P. Induction of CHOP expression by amino acid limitation requires both ATF4 expression and ATF2 phosphorylation. J Biol Chem (2004) 279(7):5288-97. doi:10.1074/ jbc.M311862200

55. Chitnis NS, Pytel D, Bobrovnikova-Marjon E, Pant D, Zheng H, Maas NL, et al. miR-211 is a prosurvival microRNA that regulates chop expression in a PERK-dependent manner. Mol Cell (2012) 48(3):353-64. doi:10.1016/j. molcel.2012.08.025

56. Woo CW, Cui D, Arellano J, Dorweiler B, Harding H, Fitzgerald KA, et al. Adaptive suppression of the ATF4-CHOP branch of the unfolded protein response by toll-like receptor signalling. Nat Cell Biol (2009) 11(12):1473-80. doi:10.1038/ncb1996

57. Woo CW, Kutzler L, Kimball SR, Tabas I. Toll-like receptor activation suppresses ER stress factor $\mathrm{CHOP}$ and translation inhibition through activation of eIF2B. Nat Cell Biol (2012) 14(2):192-200. doi:10.1038/ncb2408

58. Chiribau CB, Gaccioli F, Huang CC, Yuan CL, Hatzoglou M. Molecular symbiosis of CHOP and C/EBP beta isoform LIP contributes to endoplasmic reticulum stress-induced apoptosis. Mol Cell Biol (2010) 30(14):3722-31. doi:10.1128/mcb.01507-09

59. Erb MJ, Camacho D, Xie W, Maslikowski BM, Fielding B, Ghosh R, et al. Extracellular signal-regulated kinase 2 and $\mathrm{CHOP}$ restrict the expression of the growth arrest-specific p20K lipocalin gene to G0. Mol Cell Biol (2016) 36(23):2890-902. doi:10.1128/mcb.00338-16

60. Hetz C. The unfolded protein response: controlling cell fate decisions under ER stress and beyond. Nat Rev Mol Cell Biol (2012) 13(2):89-102. doi: $10.1038 / \mathrm{nrm} 3270$

61. Zinszner H, Kuroda M, Wang X, Batchvarova N, Lightfoot RT, Remotti H, et al. CHOP is implicated in programmed cell death in response to impaired function of the endoplasmic reticulum. Genes Dev (1998) 12(7):982-95. doi:10.1101/gad.12.7.982

62. Nam DH, Han JH, Lee TJ, Shishido T, Lim JH, Kim GY, et al. CHOP deficiency prevents methylglyoxal-induced myocyte apoptosis and cardiac dysfunction. J Mol Cell Cardiol (2015) 85:168-77. doi:10.1016/j.yjmcc.2015.05.016

63. Marciniak SJ, Yun CY, Oyadomari S, Novoa I, Zhang Y, Jungreis R, et al. $\mathrm{CHOP}$ induces death by promoting protein synthesis and oxidation in 
the stressed endoplasmic reticulum. Genes Dev (2004) 18(24):3066-77. doi:10.1101/gad.1250704

64. Salvesen GS, Ashkenazi A. Snapshot: caspases. Cell (2011) 147(2):476-e1. doi:10.1016/j.cell.2011.09.030

65. Ghosh AP, Klocke BJ, Ballestas ME, Roth KA. CHOP potentially co-operates with FOXO3a in neuronal cells to regulate PUMA and BIM expression in response to ER stress. PLoS One (2012) 7(6):e39586. doi:10.1371/journal. pone. 0039586

66. Galehdar Z, Swan P, Fuerth B, Callaghan SM, Park DS, Cregan SP. Neuronal apoptosis induced by endoplasmic reticulum stress is regulated by ATF4CHOP-mediated induction of the Bcl-2 homology 3-only member PUMA. J Neurosci (2010) 30(50):16938-48. doi:10.1523/jneurosci.1598-10.2010

67. Chen HC, Kanai M, Inoue-Yamauchi A, Tu HC, Huang Y, Ren D, et al. An interconnected hierarchical model of cell death regulation by the BCL-2 family. Nat Cell Biol (2015) 17(10):1270-81. doi:10.1038/ncb3236

68. Tuzlak S, Kaufmann T, Villunger A. Interrogating the relevance of mitochondrial apoptosis for vertebrate development and postnatal tissue homeostasis. Genes Dev (2016) 30(19):2133-51. doi:10.1101/gad.289298.116

69. Carpio MA, Michaud M, Zhou W, Fisher JK, Walensky LD, Katz SG. BCL-2 family member BOK promotes apoptosis in response to endoplasmic reticulum stress. Proc Natl Acad Sci U S A (2015) 112(23):7201-6. doi:10.1073/ pnas. 1421063112

70. Lu M, Lawrence DA, Marsters S, Acosta-Alvear D, Kimmig P, Mendez AS, et al. Opposing unfolded-protein-response signals converge on death receptor 5 to control apoptosis. Science (2014) 345(6192):98-101. doi:10.1126/ science. 1254312

71. Jung KJ, Min KJ, Bae JH, Kwon TK. Carnosic acid sensitized TRAIL-mediated apoptosis through down-regulation of c-FLIP and Bcl-2 expression at the post translational levels and CHOP-dependent up-regulation of DR5, Bim, and PUMA expression in human carcinoma caki cells. Oncotarget (2015) 6(3):1556-68. doi:10.18632/oncotarget.2727

72. Chen P, Hu T, Liang Y, Li P, Chen X, Zhang J, et al. Neddylation inhibition activates the extrinsic apoptosis pathway through ATF4-CHOP-DR5 axis in human esophageal cancer cells. Clin Cancer Res (2016) 22(16):4145-57. doi:10.1158/1078-0432.ccr-15-2254

73. van Galen P, Kreso A, Mbong N, Kent DG, Fitzmaurice T, Chambers JE, et al. The unfolded protein response governs integrity of the haematopoietic stem-cell pool during stress. Nature (2014) 510(7504):268-72. doi:10.1038/ nature 13228

74. Rao J, Zhang C, Wang P, Lu L, Qian X, Qin J, et al. C/EBP homologous protein (CHOP) contributes to hepatocyte death via the promotion of EROlalpha signalling in acute liver failure. Biochem J (2015) 466(2):369-78. doi:10.1042/ bj20140412

75. Ramming T, Okumura M, Kanemura S, Baday S, Birk J, Moes S, et al. A PDIcatalyzed thiol-disulfide switch regulates the production of hydrogen peroxide by human Ero1. Free Radic Biol Med (2015) 83:361-72. doi:10.1016/j. freeradbiomed.2015.02.011

76. Chen BL, Sheu ML, Tsai KS, Lan KC, Guan SS, Wu CT, et al. CCAATenhancer-binding protein homologous protein deficiency attenuates oxidative stress and renal ischemia-reperfusion injury. Antioxid Redox Signal (2015) 23(15):1233-45. doi:10.1089/ars.2013.5768

77. Li G, Mongillo M, Chin KT, Harding H, Ron D, Marks AR, et al. Role of ERO1-alpha-mediated stimulation of inositol 1,4,5-triphosphate receptor activity in endoplasmic reticulum stress-induced apoptosis. J Cell Biol (2009) 186(6):783-92. doi:10.1083/jcb.200904060

78. Timmins JM, Ozcan L, Seimon TA, Li G, Malagelada C, Backs J, et al. Calcium/calmodulin-dependent protein kinase II links ER stress with Fas and mitochondrial apoptosis pathways. J Clin Invest (2009) 119(10):2925-41. doi:10.1172/jci38857

79. Cheng WP, Wang BW, Lo HM, Shyu KG. Mechanical stretch induces apoptosis regulator TRB3 in cultured cardiomyocytes and volume-overloaded heart. PLoS One (2015) 10(4):e0123235. doi:10.1371/journal.pone.0123235

80. Du K, Herzig S, Kulkarni RN, Montminy M. TRB3: a tribbles homolog that inhibits Akt/PKB activation by insulin in liver. Science (2003) 300(5625):1574-7. doi:10.1126/science.1079817

81. Ohoka N, Yoshii S, Hattori T, Onozaki K, Hayashi H. TRB3, a novel ER stress-inducible gene, is induced via ATF4-CHOP pathway and is involved in cell death. EMBO J (2005) 24(6):1243-55. doi:10.1038/sj.emboj.7600596
82. Malhotra JD, Miao H, Zhang K, Wolfson A, Pennathur S, Pipe SW, et al. Antioxidants reduce endoplasmic reticulum stress and improve protein secretion. Proc Natl Acad Sci U S A (2008) 105(47):18525-30. doi:10.1073/ pnas.0809677105

83. Xu Z, Bu Y, Chitnis N, Koumenis C, Fuchs SY, Diehl JA. miR-216b regulation of c-Jun mediates GADD153/CHOP-dependent apoptosis. Nat Commun (2016) 7:11422. doi:10.1038/ncomms11422

84. Teske BF, Fusakio ME, Zhou D, Shan J, McClintick JN, Kilberg MS, et al. CHOP induces activating transcription factor 5 (ATF5) to trigger apoptosis in response to perturbations in protein homeostasis. Mol Biol Cell (2013) 24(15):2477-90. doi:10.1091/mbc.E13-01-0067

85. Mihailidou C, Chatzistamou I, Papavassiliou AG, Kiaris H. Regulation of P21 during diabetes-associated stress of the endoplasmic reticulum. Endocr Relat Cancer (2015) 22(2):217-28. doi:10.1530/ERC-15-0018

86. Mihailidou C, Chatzistamou I, Papavassiliou AG, Kiaris H. Improvement of chemotherapeutic drug efficacy by endoplasmic reticulum stress. Endocr Relat Cancer (2015) 22(2):229-38. doi:10.1530/erc-15-0019

87. Hsin IL, Hsiao YC, Wu MF, Jan MS, Tang SC, Lin YW, et al. Lipocalin 2, a new GADD153 target gene, as an apoptosis inducer of endoplasmic reticulum stress in lung cancer cells. Toxicol Appl Pharmacol (2012) 263(3):330-7. doi:10.1016/j.taap.2012.07.005

88. Thevenot PT, Sierra RA, Raber PL, Al-Khami AA, Trillo-Tinoco J, Zarreii $\mathrm{P}$, et al. The stress-response sensor chop regulates the function and accumulation of myeloid-derived suppressor cells in tumors. Immunity (2014) 41(3):389-401. doi:10.1016/j.immuni.2014.08.015

89. Southwood CM, Fykkolodziej B, Maheras KJ, Garshott DM, Estill M, Fribley $\mathrm{AM}$, et al. Overexpression of CHOP in myelinating cells does not confer a significant phenotype under normal or metabolic stress conditions. J Neurosci (2016) 36(25):6803-19. doi:10.1523/jneurosci.1118-15.2016

90. Clarke R, Cook KL, Hu R, Facey CO, Tavassoly I, Schwartz JL, et al. Endoplasmic reticulum stress, the unfolded protein response, autophagy, and the integrated regulation of breast cancer cell fate. Cancer Res (2012) 72(6):1321-31. doi:10.1158/0008-5472.CAN-11-3213

91. B'Chir W, Maurin AC, Carraro V, Averous J, Jousse C, Muranishi Y, et al. The eIF2alpha/ATF4 pathway is essential for stress-induced autophagy gene expression. Nucleic Acids Res (2013) 41(16):7683-99. doi:10.1093/nar/gkt563

92. B'Chir W, Chaveroux C, Carraro V, Averous J, Maurin AC, Jousse C, et al. Dual role for $\mathrm{CHOP}$ in the crosstalk between autophagy and apoptosis to determine cell fate in response to amino acid deprivation. Cell Signal (2014) 26(7):1385-91. doi:10.1016/j.cellsig.2014.03.009

93. Shimodaira Y, Takahashi S, Kinouchi Y, Endo K, Shiga H, Kakuta Y, et al. Modulation of endoplasmic reticulum (ER) stress-induced autophagy by C/ EBP homologous protein (CHOP) and inositol-requiring enzyme lalpha (IRElalpha) in human colon cancer cells. Biochem Biophys Res Commun (2014) 445(2):524-33. doi:10.1016/j.bbrc.2014.02.054

94. Tang ZH, Chen X, Wang ZY, Chai K, Wang YF, Xu XH, et al. Induction of C/ EBP homologous protein-mediated apoptosis and autophagy by licochalcone A in non-small cell lung cancer cells. Sci Rep (2016) 6:26241. doi:10.1038/ srep26241

95. Ke PY, Chen SS. Autophagy: a novel guardian of HCV against innate immune response. Autophagy (2011) 7(5):533-5. doi:10.4161/auto.7.5.14732

96. Rouschop KM, van den Beucken T, Dubois L, Niessen H, Bussink J, Savelkouls $\mathrm{K}$, et al. The unfolded protein response protects human tumor cells during hypoxia through regulation of the autophagy genes MAP1LC3B and ATG5. J Clin Invest (2010) 120(1):127-41. doi:10.1172/jci40027

97. Batchvarova N, Wang XZ, Ron D. Inhibition of adipogenesis by the stress-induced protein CHOP (Gadd153). EMBO J (1995) 14(19):4654-61.

98. Carriere A, Carmona MC, Fernandez Y, Rigoulet M, Wenger RH, Penicaud $\mathrm{L}$, et al. Mitochondrial reactive oxygen species control the transcription factor CHOP-10/GADD153 and adipocyte differentiation: a mechanism for hypoxia-dependent effect. J Biol Chem (2004) 279(39):40462-9. doi:10.1074/ jbc.M407258200

99. Han J, Murthy R, Wood B, Song B, Wang S, Sun B, et al. ER stress signalling through eIF2alpha and CHOP, but not IRE1alpha, attenuates adipogenesis in mice. Diabetologia (2013) 56(4):911-24. doi:10.1007/s00125-012-2809-5

100. Brenner S, Bercovich Z, Feiler Y, Keshet R, Kahana C. Dual regulatory role of polyamines in adipogenesis. J Biol Chem (2015) 290(45):27384-92. doi:10.1074/jbc.M115.686980 
101. Cartwright MJ, Tchkonia T, Kirkland JL. Aging in adipocytes: potential impact of inherent, depot-specific mechanisms. Exp Gerontol (2007) 42(6):463-71. doi:10.1016/j.exger.2007.03.003

102. Fabre O, Salehzada T, Lambert K, Boo Seok Y, Zhou A, Mercier J, et al. RNase L controls terminal adipocyte differentiation, lipids storage and insulin sensitivity via CHOP10 mRNA regulation. Cell Death Differ (2012) 19(9):1470-81. doi:10.1038/cdd.2012.23

103. Shirakawa K, Maeda S, Gotoh T, Hayashi M, Shinomiya K, Ehata S, et al. CCAAT/enhancer-binding protein homologous protein $(\mathrm{CHOP})$ regulates osteoblast differentiation. Mol Cell Biol (2006) 26(16):6105-16. doi:10.1128/ mcb.02429-05

104. Wu Y, Yang M, Fan J, Peng Y, Deng L, Ding Y, et al. Deficiency of osteoblastic Arl6ip5 impaired osteoblast differentiation and enhanced osteoclastogenesis via disturbance of ER calcium homeostasis and induction of ER stress-mediated apoptosis. Cell Death Dis (2014) 5:e1464. doi:10.1038/ cddis.2014.427

105. Yoneshima E, Okamoto K, Sakai E, Nishishita K, Yoshida N, Tsukuba T. The transcription factor EB (TFEB) regulates osteoblast differentiation through ATF4/CHOP-dependent pathway. J Cell Physiol (2016) 231(6):1321-33. doi:10.1002/jcp.25235

106. Pereira RC, Delany AM, Canalis E. CCAAT/enhancer binding protein homologous protein (DDIT3) induces osteoblastic cell differentiation. Endocrinology (2004) 145(4):1952-60. doi:10.1210/en.2003-0868

107. Saito A, Ochiai K, Kondo S, Tsumagari K, Murakami T, Cavener DR, et al. Endoplasmic reticulum stress response mediated by the PERK-eIF2(alpha)ATF4 pathway is involved in osteoblast differentiation induced by BMP2. J Biol Chem (2011) 286(6):4809-18. doi:10.1074/jbc.M110.152900

108. Alter J, Bengal E. Stress-induced C/EBP homology protein (CHOP) represses MyoD transcription to delay myoblast differentiation. PLoS One (2011) 6(12):e29498. doi:10.1371/journal.pone.0029498

109. Pina C, Teles J, Fugazza C, May G, Wang D, Guo Y, et al. Single-cell network analysis identifies DDIT3 as a nodal lineage regulator in hematopoiesis. Cell Rep (2015) 11(10):1503-10. doi:10.1016/j.celrep.2015.05.016

110. Lenna S, Trojanowska M. The role of endoplasmic reticulum stress and the unfolded protein response in fibrosis. Curr Opin Rheumatol (2012) 24(6):663-8. doi:10.1097/BOR.0b013e3283588dbb

111. Liu SH, Wu CT, Huang KH, Wang CC, Guan SS, Chen LP, et al. C/EBP homologous protein (CHOP) deficiency ameliorates renal fibrosis in unilateral ureteral obstructive kidney disease. Oncotarget (2016) 7(16):21900-12. doi:10.18632/oncotarget.7870

112. Yao Y, Wang Y, Zhang Z, He L, Zhu J, Zhang M, et al. Chop deficiency protects mice against bleomycin-induced pulmonary fibrosis by attenuating M2 macrophage production. Mol Ther (2016) 24(5):915-25. doi:10.1038/mt.2016.36

113. Pan B, Liu G, Jiang Z, Zheng D. Regulation of renal fibrosis by macrophage polarization. Cell Physiol Biochem (2015) 35(3):1062-9. doi:10.1159/000373932

114. Zhang L, Wang Y, Pandupuspitasari NS, Wu G, Xiang X, Gong Q, et al. Endoplasmic reticulum stress, a new wrestler, in the pathogenesis of idiopathic pulmonary fibrosis. Am J Transl Res (2017) 9(2):722-35.

115. Lawson WE, Cheng DS, Degryse AL, Tanjore H, Polosukhin VV, Xu XC, et al. Endoplasmic reticulum stress enhances fibrotic remodeling in the lungs. Proc Natl Acad Sci U S A (2011) 108(26):10562-7. doi:10.1073/pnas.1107559108

116. Atanelishvili I, Liang J, Akter T, Spyropoulos DD, Silver RM, Bogatkevich GS. Thrombin increases lung fibroblast survival while promoting alveolar epithelial cell apoptosis via the endoplasmic reticulum stress marker, CCAAT enhancer-binding homologous protein. Am J Respir Cell Mol Biol (2014) 50(5):893-902. doi:10.1165/rcmb.2013-0317OC

117. Gu YH, Wang Y, Bai Y, Liu M, Wang HL. Endoplasmic reticulum stress and apoptosis via PERK-eIF2alpha-CHOP signaling in the methamphetamine-induced chronic pulmonary injury. Environ Toxicol Pharmacol (2017) 49:194-201. doi:10.1016/j.etap.2017.01.003

118. Tanaka Y, Ishitsuka Y, Hayasaka M, Yamada Y, Miyata K, Endo M, et al. The exacerbating roles of CCAAT/enhancer-binding protein homologous protein $(\mathrm{CHOP})$ in the development of bleomycin-induced pulmonary fibrosis and the preventive effects of tauroursodeoxycholic acid (TUDCA) against pulmonary fibrosis in mice. Pharmacol Res (2015) 99:52-62. doi:10.1016/j. phrs.2015.05.004
119. Ayaub EA, Kolb PS, Mohammed-Ali Z, Tat V, Murphy J, Bellaye PS, et al. GRP78 and CHOP modulate macrophage apoptosis and the development of bleomycin-induced pulmonary fibrosis. J Pathol (2016) 239(4):411-25. doi:10.1002/path.4738

120. Liu SH, Yang CC, Chan DC, Wu CT, Chen LP, Huang JW, et al. Chemical chaperon 4-phenylbutyrate protects against the endoplasmic reticulum stress-mediated renal fibrosis in vivo and in vitro. Oncotarget (2016) 7(16):22116-27. doi:10.18632/oncotarget.7904

121. Zhang M, Guo Y, Fu H, Hu S, Pan J, Wang Y, et al. Chop deficiency prevents UUO-induced renal fibrosis by attenuating fibrotic signals originated from Hmgb1/TLR4/NFkappaB/IL-1beta signaling. Cell Death Dis (2015) 6:e1847. doi:10.1038/cddis.2015.206

122. Mohammed-Ali Z, Lu C, Marway MK, Carlisle RE, Ask K, Lukic D, et al. Endoplasmic reticulum stress inhibition attenuates hypertensive chronic kidney disease through reduction in proteinuria. Sci Rep (2017) 7:41572. doi:10.1038/srep41572

123. Barati MT, Powell DW, Kechavarzi BD, Isaacs SM, Zheng S, Epstein PN, et al. Differential expression of endoplasmic reticulum stress-response proteins in different renal tubule subtypes of OVE26 diabetic mice. Cell Stress Chaperones (2016) 21(1):155-66. doi:10.1007/s12192-015-0648-2

124. Tamaki N, Hatano E, Taura K, Tada M, Kodama Y, Nitta T, et al. CHOP deficiency attenuates cholestasis-induced liver fibrosis by reduction of hepatocyte injury. Am J Physiol Gastrointest Liver Physiol (2008) 294(2):G498-505. doi:10.1152/ajpgi.00482.2007

125. DeZwaan-McCabe D, Riordan JD, Arensdorf AM, Icardi MS, Dupuy AJ, Rutkowski DT. The stress-regulated transcription factor CHOP promotes hepatic inflammatory gene expression, fibrosis, and oncogenesis. PLoS Genet (2013) 9(12):e1003937. doi:10.1371/journal.pgen.1003937

126. Toriguchi K, Hatano E, Tanabe K, Takemoto K, Nakamura K, Koyama Y, et al. Attenuation of steatohepatitis, fibrosis, and carcinogenesis in mice fed a methionine-choline deficient diet by CCAAT/enhancer-binding protein homologous protein deficiency. J Gastroenterol Hepatol (2014) 29(5):110918. doi:10.1111/jgh.12481

127. Li X, Wang Y, Wang H, Huang C, Huang Y, Li J. Endoplasmic reticulum stress is the crossroads of autophagy, inflammation, and apoptosis signaling pathways and participates in liver fibrosis. Inflamm Res (2015) 64(1):1-7. doi:10.1007/s00011-014-0772-y

128. San-Miguel B, Crespo I, Sanchez DI, Gonzalez-Fernandez B, Ortiz de Urbina JJ, Tunon MJ, et al. Melatonin inhibits autophagy and endoplasmic reticulum stress in mice with carbon tetrachloride-induced fibrosis. J Pineal Res (2015) 59(2):151-62. doi:10.1111/jpi.12247

129. Churin Y, Roderfeld M, Stiefel J, Wurger T, Schroder D, Matono T, et al. Pathological impact of hepatitis B virus surface proteins on the liver is associated with the host genetic background. PLoS One (2014) 9(3):e90608. doi:10.1371/journal.pone.0090608

130. Mueller K, Sunami Y, Stuetzle M, Guldiken N, Kucukoglu O, Mueller S, et al. CHOP-mediated hepcidin suppression modulates hepatic iron load. J Pathol (2013) 231(4):532-42. doi:10.1002/path.4221

131. Malhi H, Kropp EM, Clavo VF, Kobrossi CR, Han J, Mauer AS, et al. C/ EBP homologous protein-induced macrophage apoptosis protects mice from steatohepatitis. J Biol Chem (2013) 288(26):18624-42. doi:10.1074/jbc. M112.442954

132. Du P, Ma Q, Zhu ZD, Li G, Wang Y, Li QQ, et al. Mechanism of Corilagin interference with IL-13/STAT6 signaling pathways in hepatic alternative activation macrophages in schistosomiasis-induced liver fibrosis in mouse model. Eur J Pharmacol (2016) 793:119-26. doi:10.1016/j.ejphar.2016.11.018

133. Ramachandran P, Pellicoro A, Vernon MA, Boulter L, Aucott RL, Ali A, et al. Differential Ly-6C expression identifies the recruited macrophage phenotype, which orchestrates the regression of murine liver fibrosis. Proc Natl Acad Sci U S A (2012) 109(46):E3186-95. doi:10.1073/pnas.1119964109

134. Tacke F, Zimmermann HW. Macrophage heterogeneity in liver injury and fibrosis. J Hepatol (2014) 60(5):1090-6. doi:10.1016/j.jhep.2013.12.025

135. Groenendyk J, Sreenivasaiah PK, Kim DH, Agellon LB, Michalak M. Biology of endoplasmic reticulum stress in the heart. Circ Res (2010) 107(10):1185-97. doi:10.1161/CIRCRESAHA.110.227033

136. Isodono $\mathrm{K}$, Takahashi $\mathrm{T}$, Imoto $\mathrm{H}$, Nakanishi $\mathrm{N}$, Ogata $\mathrm{T}$, Asada $\mathrm{S}$, et al. PARM-1 is an endoplasmic reticulum molecule involved in endoplasmic 
reticulum stress-induced apoptosis in rat cardiac myocytes. PLoS One (2010) 5(3):e9746. doi:10.1371/journal.pone.0009746

137. Li SJ, Liu CH, Chu HP, Mersmann HJ, Ding ST, Chu CH, et al. The high-fat diet induces myocardial fibrosis in the metabolically healthy obese minipigs-The role of ER stress and oxidative stress. Clin Nutr (2017) 36(3):760-7. doi:10.1016/j.clnu.2016.06.002

138. Fu HY, Okada K, Liao Y, Tsukamoto O, Isomura T, Asai M, et al. Ablation of C/EBP homologous protein attenuates endoplasmic reticulum-mediated apoptosis and cardiac dysfunction induced by pressure overload. Circulation (2010) 122(4):361-9. doi:10.1161/circulationaha.109.917914

139. Miyazaki Y, Kaikita K, Endo M, Horio E, Miura M, Tsujita K, et al. C/EBP homologous protein deficiency attenuates myocardial reperfusion injury by inhibiting myocardial apoptosis and inflammation. Arterioscler Thromb Vasc Biol (2011) 31(5):1124-32. doi:10.1161/atvbaha.111.224519

140. Wang M, Kaufman RJ. The impact of the endoplasmic reticulum protein-folding environment on cancer development. Nat Rev Cancer (2014) 14(9):581-97. doi:10.1038/nrc3800

141. Kim KM, Yu TK, Chu HH, Park HS, Jang KY, Moon WS, et al. Expression of ER stress and autophagy-related molecules in human non-small cell lung cancer and premalignant lesions. Int J Cancer (2012) 131(4):E362-70. doi:10.1002/ijc. 26463

142. Kan Z, Jaiswal BS, Stinson J, Janakiraman V, Bhatt D, Stern HM, et al. Diverse somatic mutation patterns and pathway alterations in human cancers. Nature (2010) 466(7308):869-73. doi:10.1038/nature09208

143. Huber AL, Lebeau J, Guillaumot P, Petrilli V, Malek M, Chilloux J, et al. p58(IPK)-mediated attenuation of the proapoptotic PERK-CHOP pathway allows malignant progression upon low glucose. Mol Cell (2013) 49(6):104959. doi:10.1016/j.molcel.2013.01.009

144. Nakagawa H, Umemura A, Taniguchi K, Font-Burgada J, Dhar D, Ogata H, et al. ER stress cooperates with hypernutrition to trigger TNF-dependent spontaneous HCC development. Cancer Cell (2014) 26(3):331-43. doi:10.1016/j.ccr.2014.07.001

145. Rodriguez R, Tornin J, Suarez C, Astudillo A, Rubio R, Yauk C, et al. Expression of FUS-CHOP fusion protein in immortalized/transformed human mesenchymal stem cells drives mixoid liposarcoma formation. Stem Cells (2013) 31(10):2061-72. doi:10.1002/stem.1472

146. Dal Cin P, Sciot R, Panagopoulos I, Aman P, Samson I, Mandahl N, et al. Additional evidence of a variant translocation $\mathrm{t}(12 ; 22)$ with EWS/CHOP fusion in myxoid liposarcoma: clinicopathological features. J Pathol (1997) 182(4):437-41. doi:10.1002/(sici)1096-9896(199708)182:4<437:aid-path882 $>3.0 . \operatorname{co} ; 2-\mathrm{x}$

147. Patil N, Ahmed Kabeer Rasheed S, Abba M, Hendrik Leupold J, Schwarzbach $\mathrm{M}$, Allgayer $\mathrm{H}$. A mechanistic study on the metastasis inducing function of FUS-CHOP fusion protein in liposarcoma. Int J Cancer (2014) 134(12):280819. doi:10.1002/ijc.28638

148. Updegraff BL, O'Donnell KA. Stressing the importance of CHOP in liver cancer. PLoS Genet (2013) 9(12):e1004045. doi:10.1371/journal.pgen.1004045

149. Scaiewicz V, Nahmias A, Chung RT, Mueller T, Tirosh B, Shibolet O. CCAAT/ enhancer-binding protein homologous (CHOP) protein promotes carcinogenesis in the DEN-induced hepatocellular carcinoma model. PLoS One (2013) 8(12):e81065. doi:10.1371/journal.pone.0081065

150. Liu K, Shi Y, Guo X, Wang S, Ouyang Y, Hao M, et al. CHOP mediates ASPP2induced autophagic apoptosis in hepatoma cells by releasing Beclin-1 from Bcl-2 and inducing nuclear translocation of Bcl-2. Cell Death Dis (2014) 5:e1323. doi:10.1038/cddis.2014.276

151. The immunosuppressive activity of MDSCs requires expression of CHOP. Cancer Discov (2014) 4(11):1254. doi:10.1158/2159-8290.cd-rw2014-204

152. Goodall JC, Wu C, Zhang Y, McNeill L, Ellis L, Saudek V, et al. Endoplasmic reticulum stress-induced transcription factor, $\mathrm{CHOP}$, is crucial for dendritic cell IL-23 expression. Proc Natl Acad Sci U S A (2010) 107(41):17698-703. doi:10.1073/pnas.1011736107

153. Wang L, Yi T, Kortylewski M, Pardoll DM, Zeng D, Yu H. IL-17 can promote tumor growth through an IL-6-Stat3 signaling pathway. J Exp Med (2009) 206(7):1457-64. doi:10.1084/jem.20090207

154. Jeong K, Kim H, Kim K, Kim SJ, Hahn BS, Jahng GH, et al. Cyclophilin $\mathrm{B}$ is involved in $\mathrm{p} 300$-mediated degradation of CHOP in tumor cell adaptation to hypoxia. Cell Death Differ (2014) 21(3):438-50. doi:10.1038/cdd. 2013.164
155. Flaherty DP, Miller JR, Garshott DM, Hedrick M, Gosalia P, Li Y, et al. Discovery of sulfonamidebenzamides as selective apoptotic CHOP pathway activators of the unfolded protein response. ACS Med Chem Lett (2014) 5(12):1278-83. doi:10.1021/ml5003234

156. Asparagine protects tumor cells from glutamine depletion-induced cell death. Cancer Discov (2014) 4(11):OF19. doi:10.1158/2159-8290.cd-rw2014-205

157. Canino C, Luo Y, Marcato P, Blandino G, Pass HI, Cioce M. A STAT3-NFkB/ DDIT3/CEBPbeta axis modulates ALDH1A3 expression in chemoresistant cell subpopulations. Oncotarget (2015) 6(14):12637-53. doi:10.18632/ oncotarget. 3703

158. Wang J, Wang L, Ho CT, Zhang K, Liu Q, Zhao H. Garcinol from Garcinia indica downregulates cancer stem-like cell biomarker ALDH1A1 in nonsmall cell lung cancer A549 cells through DDIT3 activation. J Agric Food Chem (2017) 65(18):3675-83. doi:10.1021/acs.jafc.7b00346

159. Zheng X, Jin X, Li F, Liu X, Liu Y, Ye F, et al. Inhibiting autophagy with chloroquine enhances the anti-tumor effect of high-LET carbon ions via ER stress-related apoptosis. Med Oncol (2017) 34(2):25. doi:10.1007/ s12032-017-0883-8

160. Petiwala SM, Berhe S, Li G, Puthenveetil AG, Rahman O, Nonn L, et al. Rosemary (Rosmarinus officinalis) extract modulates CHOP/GADD153 to promote androgen receptor degradation and decreases xenograft tumor growth. PLoS One (2014) 9(3):e89772. doi:10.1371/journal.pone.0089772

161. Di Giandomenico S, Frapolli R, Bello E, Uboldi S, Licandro SA, Marchini S, et al. Mode of action of trabectedin in myxoid liposarcomas. Oncogene (2014) 33(44):5201-10. doi:10.1038/onc.2013.462

162. Cao SS, Kaufman RJ. Targeting endoplasmic reticulum stress in metabolic disease. Expert Opin Ther Targets (2013) 17(4):437-48. doi:10.1517/14728 222.2013.756471

163. Biden TJ, Boslem E, Chu KY, Sue N. Lipotoxic endoplasmic reticulum stress, beta cell failure, and type 2 diabetes mellitus. Trends Endocrinol Metab (2014) 25(8):389-98. doi:10.1016/j.tem.2014.02.003

164. Mkrtchian S. Targeting unfolded protein response in cancer and diabetes. Endocr Relat Cancer (2015) 22(3):C1-4. doi:10.1530/ERC-15-0106

165. Chan JY, Luzuriaga J, Maxwell EL, West PK, Bensellam M, Laybutt DR. The balance between adaptive and apoptotic unfolded protein responses regulates beta-cell death under ER stress conditions through XBP1, CHOP and JNK. Mol Cell Endocrinol (2015) 413:189-201. doi:10.1016/j. mce.2015.06.025

166. Vomund AN, Zinselmeyer BH, Hughes J, Calderon B, Valderrama C, Ferris ST, et al. Beta cells transfer vesicles containing insulin to phagocytes for presentation to T cells. Proc Natl Acad Sci U S A (2015) 112(40):E5496-502. doi:10.1073/pnas.1515954112

167. Oyadomari S, Koizumi A, Takeda K, Gotoh T, Akira S, Araki E, et al. Targeted disruption of the Chop gene delays endoplasmic reticulum stress-mediated diabetes. J Clin Invest (2002) 109(4):525-32. doi:10.1172/jci14550

168. Song B, Scheuner D, Ron D, Pennathur S, Kaufman RJ. Chop deletion reduces oxidative stress, improves beta cell function, and promotes cell survival in multiple mouse models of diabetes. JClin Invest (2008) 118(10):3378-89. doi:10.1172/jci34587

169. Kaufman RJ, Back SH, Song B, Han J, Hassler J. The unfolded protein response is required to maintain the integrity of the endoplasmic reticulum, prevent oxidative stress and preserve differentiation in beta-cells. Diabetes Obes Metab (2010) 12(Suppl 2):99-107. doi:10.1111/j.1463-1326.2010.01281.x

170. Hamamoto S, Kanda Y, Shimoda M, Tatsumi F, Kohara K, Tawaramoto K, et al. Vildagliptin preserves the mass and function of pancreatic beta cells via the developmental regulation and suppression of oxidative and endoplasmic reticulum stress in a mouse model of diabetes. Diabetes Obes Metab (2013) 15(2):153-63. doi:10.1111/dom.12005

171. Wu YJ, Guo X, Li CJ, Li DQ, Zhang J, Yang Y, et al. Dipeptidyl peptidase-4 inhibitor, vildagliptin, inhibits pancreatic beta cell apoptosis in association with its effects suppressing endoplasmic reticulum stress in $\mathrm{db} / \mathrm{db}$ mice. Metabolism (2015) 64(2):226-35. doi:10.1016/j.metabol.2014.08.006

172. Sun X, Lin Y, Huang Q, Shi J, Qiu L, Kang M, et al. Di(2-ethylhexyl) phthalate-induced apoptosis in rat INS-1 cells is dependent on activation of endoplasmic reticulum stress and suppression of antioxidant protection. J Cell Mol Med (2015) 19(3):581-94. doi:10.1111/jcmm.12409

173. Qi Y, Xia P. Cellular inhibitor of apoptosis protein-1 (cIAP1) plays a critical role in beta-cell survival under endoplasmic reticulum stress: promoting 
ubiquitination and degradation of C/EBP homologous protein (CHOP). J Biol Chem (2012) 287(38):32236-45. doi:10.1074/jbc.M112.362160

174. Cunha DA, Hekerman P, Ladriere L, Bazarra-Castro A, Ortis F, Wakeham $\mathrm{MC}$, et al. Initiation and execution of lipotoxic ER stress in pancreatic betacells. J Cell Sci (2008) 121(Pt 14):2308-18. doi:10.1242/jcs.026062

175. Abdulkarim B, Hernangomez M, Igoillo-Esteve M, Cunha DA, Marselli L, Marchetti P, et al. Guanabenz sensitizes pancreatic beta cells to lipotoxic endoplasmic reticulum stress and apoptosis. Endocrinology (2017) 158(6):1659-70. doi:10.1210/en.2016-1773

176. Gurlo T, Rivera JF, Butler AE, Cory M, Hoang J, Costes S, et al. CHOP contributes to, but is not the only mediator of, IAPP induced beta-cell apoptosis. Mol Endocrinol (2016) 30(4):446-54. doi:10.1210/me.2015-1255

177. Wali JA, Rondas D, McKenzie MD, Zhao Y, Elkerbout L, Fynch S, et al. The proapoptotic BH3-only proteins Bim and Puma are downstream of endoplasmic reticulum and mitochondrial oxidative stress in pancreatic islets in response to glucotoxicity. Cell Death Dis (2014) 5:e1124. doi:10.1038/ cddis. 2014.88

178. Mihailidou C, Papavassiliou AG, Kiaris H. A crosstalk between p21 and UPRinduced transcription factor C/EBP homologous protein (CHOP) linked to type 2 diabetes. Biochimie (2014) 99:19-27. doi:10.1016/j.biochi.2013.11.003

179. Duan H, Arora D, Li Y, Setiadi H, Xu D, Lim HY, et al. Identification of 1,2,3-triazole derivatives that protect pancreatic beta cells against endoplasmic reticulum stress-mediated dysfunction and death through the inhibition of C/EBP-homologous protein expression. Bioorg Med Chem (2016) 24(12):2621-30. doi:10.1016/j.bmc.2016.03.057

180. Allagnat F, Fukaya M, Nogueira TC, Delaroche D, Welsh N, Marselli L, et al. C/EBP homologous protein contributes to cytokine-induced pro-inflammatory responses and apoptosis in beta-cells. Cell Death Differ (2012) 19(11):1836-46. doi:10.1038/cdd.2012.67

181. Brozzi F, Nardelli TR, Lopes M, Millard I, Barthson J, Igoillo-Esteve M, et al. Cytokines induce endoplasmic reticulum stress in human, rat and mouse beta cells via different mechanisms. Diabetologia (2015) 58(10):2307-16. doi:10.1007/s00125-015-3669-6

182. Sartori DJ, Wilbur CJ, Long SY, Rankin MM, Li C, Bradfield JP, et al. GATA factors promote ER integrity and beta-cell survival and contribute to type 1 diabetes risk. Mol Endocrinol (2014) 28(1):28-39. doi:10.1210/ me.2013-1265

183. Wu J, Zhang R, Torreggiani M, Ting A, Xiong H, Striker GE, et al. Induction of diabetes in aged C57B6 mice results in severe nephropathy: an association with oxidative stress, endoplasmic reticulum stress, and inflammation. Am J Pathol (2010) 176(5):2163-76. doi:10.2353/ajpath.2010.090386

184. Liu Z, Zhao N, Zhu H, Zhu S, Pan S, Xu J, et al. Circulating interleukin-1beta promotes endoplasmic reticulum stress-induced myocytes apoptosis in diabetic cardiomyopathy via interleukin-1 receptor-associated kinase-2. Cardiovasc Diabetol (2015) 14:125. doi:10.1186/s12933-015-0288-y

185. Yu H, Zhen J, Yang Y, Gu J, Wu S, Liu Q. Ginsenoside Rg1 ameliorates diabetic cardiomyopathy by inhibiting endoplasmic reticulum stress-induced apoptosis in a streptozotocin-induced diabetes rat model. J Cell Mol Med (2016) 20(4):623-31. doi:10.1111/jcmm.12739

186. Lupachyk S, Watcho P, Stavniichuk R, Shevalye H, Obrosova IG. Endoplasmic reticulum stress plays a key role in the pathogenesis of diabetic peripheral neuropathy. Diabetes (2013) 62(3):944-52. doi:10.2337/db12-0716

187. Zeng XS, Jia JJ, Kwon Y, Wang SD, Bai J. The role of thioredoxin-1 in suppression of endoplasmic reticulum stress in Parkinson disease. Free Radic Biol Med (2014) 67:10-8. doi:10.1016/j.freeradbiomed.2013.10.013

188. Cabral Miranda F, Adao-Novaes J, Hauswirth WW, Linden R, Petrs-Silva H, Chiarini LB. CHIP, a carboxy terminus HSP-70 interacting protein, prevents cell death induced by endoplasmic reticulum stress in the central nervous system. Front Cell Neurosci (2014) 8:438. doi:10.3389/fncel.2014.00438

189. Hetz C, Mollereau B. Disturbance of endoplasmic reticulum proteostasis in neurodegenerative diseases. Nat Rev Neurosci (2014) 15(4):233-49. doi:10.1038/nrn3689

190. Baleriola J, Walker CA, Jean YY, Crary JF, Troy CM, Nagy PL, et al. Axonally synthesized ATF4 transmits a neurodegenerative signal across brain regions. Cell (2014) 158(5):1159-72. doi:10.1016/j.cell.2014.07.001

191. Marwarha G, Rostad S, Lilek J, Kleinjan M, Schommer J, Ghribi O. Palmitate increases beta-site AbetaPP-cleavage enzyme 1 activity and amyloid-beta genesis by evoking endoplasmic reticulum stress and subsequent C/EBP homologous protein activation. J Alzheimers Dis (2017) 57(3):907-25. doi:10.3233/jad-161130

192. Marwarha G, Raza S, Prasanthi JR, Ghribi O. Gadd153 and NF-kappaB crosstalk regulates 27-hydroxycholesterol-induced increase in BACE1 and beta-amyloid production in human neuroblastoma SH-SY5Y cells. PLoS One (2013) 8(8):e70773. doi:10.1371/journal.pone.0070773

193. Marwarha G, Dasari B, Ghribi O. Endoplasmic reticulum stress-induced $\mathrm{CHOP}$ activation mediates the down-regulation of leptin in human neuroblastoma SH-SY5Y cells treated with the oxysterol 27-hydroxycholesterol. Cell Signal (2012) 24(2):484-92. doi:10.1016/j.cellsig.2011.09.029

194. Aime P, Sun X, Zareen N, Rao A, Berman Z, Volpicelli-Daley L, et al. Trib3 is elevated in Parkinson's disease and mediates death in Parkinson's disease models. J Neurosci (2015) 35(30):10731-49. doi:10.1523/jneurosci.0614-15.2015

195. Zhang GF, Zhang Y, Zhao G. Crocin protects PC12 cells against MPP(+)induced injury through inhibition of mitochondrial dysfunction and ER stress. Neurochem Int (2015) 89:101-10. doi:10.1016/j.neuint.2015.07.011

196. Pennuto M, Tinelli E, Malaguti M, Del Carro U, D’Antonio M, Ron D, et al. Ablation of the UPR-mediator CHOP restores motor function and reduces demyelination in Charcot-Marie-Tooth 1B mice. Neuron (2008) 57(3):393-405. doi:10.1016/j.neuron.2007.12.021

197. D’Antonio M, Musner N, Scapin C, Ungaro D, Del Carro U, Ron D, et al. Resetting translational homeostasis restores myelination in Charcot-MarieTooth disease type 1B mice. J Exp Med (2013) 210(4):821-38. doi:10.1084/ jem.20122005

198. Saporta MA, Shy BR, Patzko A, Bai Y, Pennuto M, Ferri C, et al. MpzR98C arrests Schwann cell development in a mouse model of early-onset CharcotMarie-Tooth disease type 1B. Brain (2012) 135(Pt 7):2032-47. doi:10.1093/ brain/aws140

199. Dametto P, Lakkaraju AK, Bridel C, Villiger L, O’Connor T, Herrmann US, et al. Neurodegeneration and unfolded-protein response in mice expressing a membrane-tethered flexible tail of PrP. PLoS One (2015) 10(2):e0117412. doi:10.1371/journal.pone.0117412

200. Ohri SS, Maddie MA, Zhao Y, Qiu MS, Hetman M, Whittemore SR. Attenuating the endoplasmic reticulum stress response improves functional recovery after spinal cord injury. Glia (2011) 59(10):1489-502. doi:10.1002/ glia. 21191

201. Lopez-Hernandez B, Cena V, Posadas I. The endoplasmic reticulum stress and the HIF-1 signalling pathways are involved in the neuronal damage caused by chemical hypoxia. Br J Pharmacol (2015) 172(11):2838-51. doi:10.1111/bph.13095

202. Hu Y, Park KK, Yang L, Wei X, Yang Q, Cho KS, et al. Differential effects of unfolded protein response pathways on axon injury-induced death of retinal ganglion cells. Neuron (2012) 73(3):445-52. doi:10.1016/j. neuron.2011.11.026

203. Miao G, Zhao YG, Zhao H, Ji C, Sun H, Chen Y, et al. Mice deficient in the Vici syndrome gene Epg5 exhibit features of retinitis pigmentosa. Autophagy (2016) 12(12):2263-70. doi:10.1080/15548627.2016.1238554

204. Shah A, Kumar A. Methamphetamine-mediated endoplasmic reticulum (ER) stress induces type-1 programmed cell death in astrocytes via ATF6, IRElalpha and PERK pathways. Oncotarget (2016) 7(29):46100-19. doi:10.18632/oncotarget.10025

205. Liu B, Xia J, Chen Y, Zhang J. Sevoflurane-induced endoplasmic reticulum stress contributes to neuroapoptosis and BACE-1 expression in the developing brain: the role of eIF2alpha. Neurotox Res (2017) 31(2):218-29. doi:10.1007/s12640-016-9671-z

206. Marwarha G, Claycombe K, Schommer J, Collins D, Ghribi O. Palmitateinduced endoplasmic reticulum stress and subsequent C/EBPalpha homologous protein activation attenuates leptin and insulin-like growth factor 1 expression in the brain. Cell Signal (2016) 28(11):1789-805. doi:10.1016/j. cellsig.2016.08.012

207. Wang Y, Kuramitsu Y, Baron B, Kitagawa T, Akada J, Tokuda K, et al. PERK/ CHOP contributes to the CGK733-induced vesicular calcium sequestration which is accompanied by non-apoptotic cell death. Oncotarget (2015) 6(28):25252-65. doi:10.18632/oncotarget.4487

208. Zhang N, Bi C, Liu L, Dou Y, Tang S, Pang W, et al. IMB-6G, a novel $\mathrm{N}$-substituted sophoridinic acid derivative, induces endoplasmic reticulum stress-mediated apoptosis via activation of IRE1alpha and PERK signaling. Oncotarget (2016) 7(17):23860-73. doi:10.18632/oncotarget.8184 
209. Pennati M, Sbarra S, De Cesare M, Lopergolo A, Locatelli SL, Campi E, et al. YM155 sensitizes triple-negative breast cancer to membrane-bound TRAIL through p38 MAPK- and CHOP-mediated DR5 upregulation. Int J Cancer (2015) 136(2):299-309. doi:10.1002/ijc.28993

210. Kim H, Shin EA, Kim CG, Lee DY, Kim B, Baek NI, et al. Obovatol induces apoptosis in non-small cell lung cancer cells via C/EBP homologous protein activation. Phytother Res (2016) 30(11):1841-7. doi:10.1002/ptr.5690

211. Wang B, Zhao XH. Apigenin induces both intrinsic and extrinsic pathways of apoptosis in human colon carcinoma HCT-116 cells. Oncol Rep (2017) 37(2):1132-40. doi:10.3892/or.2016.5303

212. He K, Zheng X, Li M, Zhang L, Yu J. mTOR inhibitors induce apoptosis in colon cancer cells via CHOP-dependent DR5 induction on 4E-BP1 dephosphorylation. Oncogene (2016) 35(2):148-57. doi:10.1038/onc.2015.79

213. Kikuchi S, Suzuki R, Ohguchi H, Yoshida Y, Lu D, Cottini F, et al. Class IIa HDAC inhibition enhances ER stress-mediated cell death in multiple myeloma. Leukemia (2015) 29(9):1918-27. doi:10.1038/leu.2015.83

214. Rosilio C, Nebout M, Imbert V, Griessinger E, Neffati Z, Benadiba J, et al. L-type amino-acid transporter 1 (LAT1): a therapeutic target supporting growth and survival of T-cell lymphoblastic lymphoma/T-cell acute lymphoblastic leukemia. Leukemia (2015) 29(6):1253-66. doi:10.1038/leu.2014.338

215. Buontempo F, Orsini E, Martins LR, Antunes I, Lonetti A, Chiarini F, et al. Cytotoxic activity of the casein kinase 2 inhibitor CX-4945 against T-cell acute lymphoblastic leukemia: targeting the unfolded protein response signaling. Leukemia (2014) 28(3):543-53. doi:10.1038/leu.2013.349
216. Fribley AM, Miller JR, Brownell AL, Garshott DM, Zeng Q, Reist TE, et al. Celastrol induces unfolded protein response-dependent cell death in head and neck cancer. Exp Cell Res (2015) 330(2):412-22. doi:10.1016/j. yexcr.2014.08.014

217. Tsai SF, Tao M, Ho LI, Chiou TW, Lin SZ, Su HL, et al. Isochaihulactoneinduced DDIT3 causes ER stress-PERK independent apoptosis in glioblastoma multiforme cells. Oncotarget (2017) 8(3):4051-61. doi:10.18632/ oncotarget.13266

Conflict of Interest Statement: We declare that none of the authors have any financial and personal relationships with other people or a third party that can inappropriately influence the quality of the work presented in this manuscript. There is no professional or other personal interest of any nature or kind in any product, service, and/or company that could be construed as influencing the position presented in, or the review of, the manuscript entitled, "Transcription Factor C/EBP Homologous Protein (CHOP) in Diseases."

Copyright ( 2017 Yang, Liu, Naik, Braunstein, Zhong and Ren. This is an open-access article distributed under the terms of the Creative Commons Attribution License (CC $B Y)$. The use, distribution or reproduction in other forums is permitted, provided the original author(s) or licensor are credited and that the original publication in this journal is cited, in accordance with accepted academic practice. No use, distribution or reproduction is permitted which does not comply with these terms. 